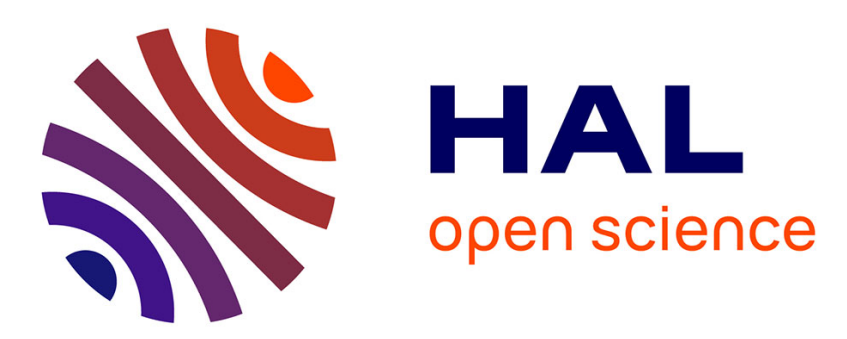

\title{
Tidal transport and dispersal of marine toxic microalgae in a shallow, temperate coastal lagoon
}

\author{
M. Cerejo, J.M. Dias
}

\section{To cite this version:}

M. Cerejo, J.M. Dias. Tidal transport and dispersal of marine toxic microalgae in a shallow, temperate coastal lagoon. Marine Environmental Research, 2007, 63 (4), pp.313. 10.1016/j.marenvres.2006.10.005 . hal-00501892

\section{HAL Id: hal-00501892 \\ https://hal.science/hal-00501892}

Submitted on 13 Jul 2010

HAL is a multi-disciplinary open access archive for the deposit and dissemination of scientific research documents, whether they are published or not. The documents may come from teaching and research institutions in France or abroad, or from public or private research centers.
L'archive ouverte pluridisciplinaire $\mathbf{H A L}$, est destinée au dépôt et à la diffusion de documents scientifiques de niveau recherche, publiés ou non, émanant des établissements d'enseignement et de recherche français ou étrangers, des laboratoires publics ou privés. 


\section{Accepted Manuscript}

Tidal transport and dispersal of marine toxic microalgae in a shallow, temperate coastal lagoon

M. Cerejo, J.M. Dias

PII:

S0141-1136(06)00190-5

DOI:

10.1016/j.marenvres.2006.10.005

Reference:

MERE 3071

To appear in:

Marine Environmental Research

Received Date: $\quad 10$ January 2006

Revised Date: $\quad 26$ September 2006

Accepted Date: $\quad 6$ October 2006

Please cite this article as: Cerejo, M., Dias, J.M., Tidal transport and dispersal of marine toxic microalgae in a shallow, temperate coastal lagoon, Marine Environmental Research (2006), doi: 10.1016/j.marenvres.2006.10.005

This is a PDF file of an unedited manuscript that has been accepted for publication. As a service to our customers we are providing this early version of the manuscript. The manuscript will undergo copyediting, typesetting, and review of the resulting proof before it is published in its final form. Please note that during the production process errors may be discovered which could affect the content, and all legal disclaimers that apply to the journal pertain. 


\title{
TIDAL TRANSPORT AND DISPERSAL OF MARINE TOXIC MICROALGAE IN A SHALLOW, TEMPERATE COASTAL LAGOON
}

\author{
M. Cerejo ${ }^{1} *$ and J.M. Dias ${ }^{1}$ \\ ${ }^{1}$ Departamento de Física, Universidade de Aveiro, 3810-193 Aveiro, \\ Portugal.
}

Corresponding author: marta.cerejo@gmail.com

\begin{abstract}
A numerical model was used to predict toxic microalgal transport and dispersion in Ria de Aveiro in Portugal. A previously developed Lagrangean particle tracking model coupled to a calibrated two-dimensional hydrodynamic model of Ria de Aveiro was used. Microalgae were regarded as passive particles and the methodology used allowed the determination of their trajectories, as induced by the tidal currents predicted by the hydrodynamic model. The model assumes Ria de Aveiro as verticaly homogeneous and does not take into account the vertical distribution patterns of microalgae. Simulations were carried out during extreme spring and neap tides, with microalgal released at the mouth of the lagoon at the local flood. The maximum and minimum areas affected during the occurrence of toxic microalgal blooms were estimated to evaluate the suitability of the distribution of the sampling stations included in the local monitoring program. It was found that the tidal currents greatly determine
\end{abstract}


the microalgal horizontal distribution and dispersal in the lagoon. The results confirmed that the locations of water and bivalve shellfish sampling stations, postulated by INIAP/IPIMAR, in the context of the local harmful algal bloom (HAB) program, were appropriate, although some possible refinements were identified.

Key words: Toxic microalgae, monitoring, transport, bivalve shellfish, numerical modelling, Ria de Aveiro

\section{Introduction}

Ria de Aveiro is a shallow coastal lagoon located on the Northwest Atlantic Portuguese coast $\left(40^{\circ} 38^{\prime} \mathrm{N}, 8^{\circ} 45^{\prime} \mathrm{W}\right)$ (Dias, Lopes \& Dekeyser, 2003) repeatedly affected by harmful algae blooms (HABs) and resulting contamination of bivalve shellfish, especially of the diarrhetic shellfish poisoning (DSP) type (Vale, 2004; Moita \& Silva, 2001; Palma et al., 1998). This situation constitutes a threat to public health and has strong negative impacts in the economy of the area. In fact, shellfish exploitation and related businesses (such as depuration plants) constitutes the most important economic activity, related to the fishing resources, of Ria de Aveiro. The bivalve harvest takes place most of the year, except in periods of phycotoxin occurrence. These toxins become accumulated in the shellfish tissues that, when latter consumed by humans, cause a variety of gastrointestinal illnesses (Valiela, 1995; Hallegraeff, 2003; FAO, 2004; IOC, 2005). In periods of phycotoxins occurrence the competent authorities ban the 
harvesting and sale of shellfish, safeguarding public health but harming the economy of the area (Sobral et al., 2000).

The HABs impacts on public health and economy appear to have increased in frequency, intensity and geographical distribution in the past two decades (Hallegraeff, 2003). These toxic events are predominantly coastal phenomena and their effects are most apparent on coastal biota. Much of the global production of seafood and exploitation of fish and shellfish resources is situated within the coastal zone. The monitor and control of HABs is, therefore, of critical importance to coastal-zone management of marine resources and protection of public health (Cembella et al., 2005).

In Portugal, the task of monitoring and controlling harmful algal blooms is performed by Instituto Nacional de Investigação Agrária e das Pescas (INIAP/IPIMAR). To accomplish this task, water and shellfish samples are collected at various sampling stations, located along the Portuguese coast, as part of the project Plano Nacional de Salubridade de Bivalves, in order to quantify the number of toxic phytoplankton cells per litre of and the toxicity found in different species of shellfish.

For the purpose of contributing to the optimization of the monitoring program of HABs developed in Ria de Aveiro, it is considered important to study and understand how the tidal flow induces the horizontal transport and dispersal of toxic microalgae in this lagoon and if there are any areas where microalgae are retained. The methodology adopted in this work comprises the application of a previously developed Lagrangean particle tracking model (Dias et al., 2001; 2003) coupled to a calibrated two-dimensional 
hydrodynamic model of Ria de Aveiro (Dias \& Lopes, 2006a,b). This study provides an example of the applicability of the numerical modelling in the management of coastal areas and shows ways of improving the sampling design of a monitoring program.

The microalgae were considered as passive particles, assuming absence of an effective means of locomotion. Their movement is assumed to be entirely induced by the tidal currents and the modelling system allows the following of their trajectories. Simulations were carried out during extreme spring and neap tides, with particles being released at the mouth of the lagoon on the local flood tide. The maximum and minimum areas affected during the occurrence HAB's were estimated in order to evaluate whether the distribution of sampling stations included in the monitoring program is adequate. The maximum and minimum residence times of microalgae in the lagoon, as well as for each channel were estimated. This work was carried out with no wind conditions and in the absence of river discharges, which maximize the residence time.

\section{Study area - Ria de Aveiro}

Ria de Aveiro is physically and biogeochemically a dynamic aquatic ecosystem on the Portuguese coast (Dias, 2001). Biologically it is considered to be rich in nutrients and organic matter. It therefore constitutes a highly productive environment, that provides a habitat for several commercially important fish and invertebrate species. This lagoon provides natural conditions for economic activities, like industry, navigation and 
recreation, enduring pressure from the large human population that inhabits its margins and depends upon its resources (Barrosa, 1985; Dias et al., 2001).

The lagoon is $45 \mathrm{~km}$ long and $10 \mathrm{~km}$ wide (Figure 1) and on spring tide covers an area of $83 \mathrm{~km}^{2}$ at high tide, which is reduced to $66 \mathrm{~km}^{2}$ at low tide (Barrosa, 1985; Dias et al., 2001). It comprises a complex dendritic pattern of channels characterised by the existence of significant intertidal zones, namely mud flats and salt marshes (Dias et al., 2001), where extensive natural banks of shellfish occur. It is connected to the Atlantic Ocean through an artificial channel on the west side and it exchanges most of its water with the ocean by tidal input across this narrow entrance (Vicente, 1985; Dias et al., 2001).

The numerous channels that constitute Ria de Aveiro are here reduced to the four main branches radiating from the sea entrance (Entrance channel): Mira, S.Jacinto, Ílhavo and Espinheiro channels (Figure 1). Each of these channels has individual hydrological characteristics, and for this reason may be considered as presenting features of separate estuaries (Dias, Lopes \& Dekeyser, 1999).

The average depth of the lagoon is about $1 \mathrm{~m}$ relative to the local chart datum (2.00 metres below mean sea level), but in the inlet channel the depth is higher than $20 \mathrm{~m}$. The other navigable channels, where dredging operations are frequently carried out, are about $7 \mathrm{~m}$ deep (Dias et al., 2001). 
Ria de Aveiro is a mesotidal lagoon and the tides, which are semidiurnal, are the main forcing action, with a mean tidal range of about $2 \mathrm{~m}$ (Vicente, 1985; Dias et al., 2001; Dias \& Lopes, 2006b). Dias et al. (1999) documented the minimum and maximum registered tidal ranges as $0.6 \mathrm{~m}$ (neap tide) and $3.2 \mathrm{~m}$ (spring tide), respectively. The tide propagates from the mouth as a mixed progressive and standing wave and it is present in the entire lagoon. It generates strong currents in deep and narrow channels, but not in the intertidal areas (Dias et al., 2001). There is a small artificial headland (Triângulo Divisor das Correntes) dividing the Entrance channel in two different arms. Due to this feature the flood flow is divided in two different currents: a small one flowing into Mira channel and a second and more important one flowing to the other channels, namely S. Jacinto and Espinheiro channels, in which tidal current amplitudes may achieve values higher than $1 \mathrm{~m} \mathrm{~s}^{-1}$ (Vicente, 1985; Dias, 2001; Dias et al., 2001).

Only extreme conditions of strong wind may induce particular circulation patterns in Ria de Aveiro, mainly in shallow areas and in the wider channels (Dias et al., 2003). However, according to the local wind climate, strong and persistent winds are rare events (Dias, 2001).

The lagoon receives freshwater mainly from two rivers, Antuã $\left(5 \mathrm{~m}^{3} \mathrm{~s}^{-1}\right.$ average flow) and Vouga $\left(50 \mathrm{~m}^{3} \mathrm{~s}^{-1}\right)$ (Vicente, 1985; Dias et al., 2003; Dias \& Lopes, 2006a). The Boco river, at the southern end of Ílhavo channel, has a negligible flow, and the same applies to the Caster and Gonde rivers, discharging at the north end of S. Jacinto channel. There is another freshwater source at the southern end of Mira channel that consists of a 
small system of ponds and rivers connected by a small dam called Barrinha de Mira, the flow of which is not well known (Dias et al., 2003; Dias \& Lopes, 2006a).

The estimated maximum and minimum tidal prism of the lagoon is $136.7 \times 10^{6} \mathrm{~m}^{3}$ and $34.9 \times 10^{6} \mathrm{~m}^{3}$ for the extreme spring and neap tides, respectively (Dias, 2001). The total estimated freshwater input in a spring tide is small (about $1.8 \times 10^{6} \mathrm{~m}^{3}$ during a tidal cycle) when compared with the mean tidal prism at the mouth (about $70 \times 10^{6} \mathrm{~m}^{3}$ ).

A prior hydrological characterization of Ria de Aveiro lead to the conclusion that the lagoon can be considered vertically homogeneous (Dias et al, 1999).

\section{Marine toxic microalgae}

Among the 5000 species of extant marine phytoplankton, some 300 species can at times occur in such high numbers that they discolour the surface of the sea (so-called 'red tides'), while only about 80 species have the capacity to produce potent toxins that can find their way through fish and shellfish to humans (Sournia, Chretiennot-Dinet \& Ricard, 1991; Hallegraeff, 2003).

Essentially there are 3 kinds of illnesses caused by the ingestion of bivalve shellfish contaminated by toxins produced by phytoplankton cells: paralytic shellfish poisoning (PSP); amnesic shellfish poisoning (ASP); and diarrhetic shellfish poisoning (DSP).

Ria de Aveiro is one of the most affected locations by blooms of Dinophysis acuminata and D. acuta, which are responsible for DSP events (Moita, 
1993; Vale, Cerejo \& Vilarinho, 2004; Moita et al., 2005). The first confirmed occurrence of diarrhetic toxins (okadaic acid, dinophysistoxins and pectenotoxins) in Portugal associated with Dinophysis was registered in 1987 (Sampayo, Alvito, Franca \& Sousa, 1990). Except for 1993, DSP events occur every year, especially from late spring until mid-autumn (Palma et al. 1998). Most Dinophysis species are associated with upwelling relaxation on the Portuguese northwest coast, and the largest numbers of cells per litre are encountered on conditions of stratification (Palma et al., 1998; Moita et al., 2005). Dinophysis acuminata blooms, adapted to lower temperature and salinity, occur mainly in spring and summer. Dinophysis acuta blooms have their epicentre in Figueira da Foz - Aveiro region, during hot and dry summers and can be transported northward by currents that are established at the end of summer (Moita et al., 2005). They enter Ria de Aveiro lagoon, contaminating the existing bivalve shellfish banks causing negative impacts on the economy of the Aveiro region.

In the context of the monitoring program of toxic events defined for Ria de Aveiro, periodic collection of water samples is conducted at four sampling stations (Figure 1), namely, Marégrafo (at the mouth of the lagoon) sampled twice a week, Triângulo das Correntes (Entrance channel) and Moacha (S. Jacinto channel) sampled once a week, and Canal de Mira (Mira channel), sampled only when toxic microalgae occur. These samples are used for the identification and quantification of phytoplankton species known to be toxic. 
The variation in abundance of Dinophysis acuminata and D. acuta from March 2004 to May 2005, obtained from the analysis of the samples previously collected at the four sampling stations already mentioned, is presented in Figure 2. Time series were obtained for Marégrafo, Triângulo das Correntes and Moacha sampling stations, as well as a representation of the abundance of the same species during alert periods in Mira channel sampling station.

D. acuminata was more abundant between May and June 2004, while $D$. acuta occurred in the months of September, October and November of the same year. Both species occurred in larger concentrations in the sampling stations located at Ria de Aveiro Entrance channel - Marégrafo and Triângulo das Correntes. Therefore, the toxic microalgae in question occur in Ria de Aveiro and are particularly abundant at the end of summer and beginning of autumn, justifying the choice of the period of September 2004 to perform the simulations presented in this study.

\section{Bivalve Shellfish}

Bivalve shellfish are filter feeders that inhabit the intertidal zone. They filter large quantities of water from which they withdraw microscopic food particles, such as phytoplankton cells. Filter feeders pump the ambient water through filters that retain suspended matter, usually irrespective of whether this matter is of food value or not (Jørgensen, 1990). When toxic phytoplankton cells are abundant in the water column they will be ingested and their toxins accumulated in the bivalve shellfish tissues. 
Natural production banks of bivalve shellfish are common in Ria de Aveiro lagoon, existing in almost every channel, but mostly in the central part of the lagoon, and particularly in areas close to the entrance (Sobral, personal communication).

In the context of the national program of HABs monitoring on the Portuguese coast, Ria de Aveiro is one of the locations most frequently sampled. A variety of bivalve shellfish sampling stations exist along the lagoon: blue mussels (Mytilus edulis) are collected every week at the Entrance channel, twice a month in S. Jacinto channel and once a month in Espinheiro channel; common cockles (Cerastoderma edule) are sampled every week at S. Jacinto channel, and once a month in Espinheiro and Ílhavo channel; carpet shells (Venerrupis pullastra) are collected twice a month in Mira channel and once a month in Espinheiro channel; and razor shells (Solen marginatus) are sampled twice a month in Mira channel. Due to the decrease of natural production banks of cockle shell in Ria de Aveiro lagoon, this species, as well as oysters, is sampled from the existing molluscan shellfish farm of Costa Nova, with a monthly periodicity.

The location of the sampling stations was determined by INIAP/IPIMAR considering the largest existing production banks, their relative commercial exploitation and the existing points for microbiological assessment of water quality. 


\section{Methods}

One of the most common tools in the study of coastal zones, lagoons and estuaries are numerical models which are increasingly applied in the planning and management of hydrologic basins (Santos \& Costa, 1985).

In shallow coastal water systems, the mathematical modelling of physical processes is well developed and some models are considered to be in a mature stage. This is the case for two-dimensional vertically integrated (2HD) hydrodynamic models.

\subsection{Hydrodynamic model}

In view of the hydrodynamic characteristics of the study domain, Ria de Aveiro, a two-dimensional vertically integrated hydrodynamic model (2HD) based on finite differences techniques was considered suitable for the simulation of the lagoon's hydrodynamics by Dias (2001). This model was developed from the SIMSYS2D model (Leendertse \& Gritton, 1971; Leendertse, 1987) and solves the second order partial differential equations for the depth average fluid flow (shallow water equations) derived from the full three-dimensional Navier-Stokes equations (Dias \& Lopes, 2006a,b):

$$
\begin{aligned}
& \frac{\partial \zeta}{\partial t}+\frac{\partial(H U)}{\partial x_{1}}+\frac{\partial(H V)}{\partial x_{2}}=0 \\
& \frac{\partial U}{\partial t}+U \frac{\partial U}{\partial x_{1}}+V \frac{\partial U}{\partial x_{2}}=f V-g \frac{\partial \zeta}{\partial x_{1}}-\frac{\tau_{x_{1}}^{b}}{H \rho_{0}}+A_{h} \nabla^{2} U
\end{aligned}
$$




$$
\frac{\partial V}{\partial t}+U \frac{\partial V}{\partial x_{1}}+V \frac{\partial V}{\partial x_{2}}=-f U-g \frac{\partial \zeta}{\partial x_{2}}-\frac{\tau_{x_{2}}^{b}}{H \rho_{0}}+A_{h} \nabla^{2} V
$$

where $U$ is the depth integrated velocity component in the $x_{1}$ direction (eastward); $V$ is the depth integrated velocity component in the $x_{2}$ direction (northward); $\xi$ is the surface water elevation; $H$ is the water height; $t$ is the time; $f$ is the Coriolis parameter; $g$ is the acceleration of gravity; $\rho$ is the water density; $A_{h}$ is the kinematic constant turbulent horizontal viscosity; and $\tau^{b}$ is the magnitude of the shear stress on the bottom caused by the flow of water over the bed.

The last parameter, $\tau^{b}$, is related to the frictional dissipation of momentum at the water-sediment interface and it is approximated by a quadratic drag law using the Manning-Chezy formulation (Dronkers, 1964; Dias et al., 2003).

The system of equations (1)-(3) was discretized using a finite difference method and the difference equations solved by the ADI method (alternating direction implicit), using a space-staggered grid (Leendertse \& Gritton, 1971; Dias et al., 2003).

With appropriate boundary and initial conditions, this system of equations constitutes a well-posed initial boundary value problem whose solution describes the depth-averaged circulation in a tidal basin (Dias et al., 2003).

At the ocean open boundary the water elevation over the reference level was imposed by using tidal predictions determined from the web page Tidal Prediction for the Western Iberian Peninsula (URL: 
http://neptuno.fis.ua.pt/tidal). The initial conditions were horizontal level and null velocity in all the grid points. Along the solid boundaries a null normal velocity was imposed and a free slip condition was assumed (Dias et al., 2003).

The model grid has dimensions $\Delta x=\Delta y=100 \mathrm{~m}$, resulting in 160 cells in the $x_{1}$ direction (eastward) and 393 cells in the $x_{2}$ direction (northward). A computational time step of $40 \mathrm{~s}$ was used, with a 3 day spin up period. A typical value of $20 \mathrm{~m}^{2} \mathrm{~s}^{-1}$ was adopted for $A_{h}$, in order to increase the stability of the numerical solution.

The hydrodynamic model was calibrated and validated for Ria de Aveiro by Dias \& Lopes $(2006 \mathrm{a}, \mathrm{b})$. The results indicated that the hydrodynamic model accurately predicts the water level and the currents in the lagoon.

\subsection{Particle-tracking model}

Lagrangean modelling constitutes a powerful tool for studying the processes of dispersion in coastal waters, estuaries and lagoons (Gomez-Gesteira et al., 1999; Inoue \& Wiseman, 2000; Dias, 2001). They are now widely applied in the study of transport of passive particles in coastal areas (Hofmann et al., 1991; Gomez-Gesteira et al., 1999; Dias, 2001).

In recovering Lagrangean information from a Eulerian currents data set, the purpose is to obtain Lagrangean particle trajectories, $X_{i}^{n}$, given an Eulerian velocity field, $U_{i}\left(X_{i}^{n}, t\right)$, by integrating the following equation:

$\frac{d X_{i}^{n}}{d t}=U_{i}\left(X_{i}^{n}, t\right)$ 
where particles are identified as $i=1,2, \ldots$, and the vectors $X_{i}^{n}$ and $U_{i}$ give the 2-D particle positions and velocities (Dias, 2001; Dias et al., 2003).

Therefore, the two-dimensional trajectories of the simulated particles are computed using a Lagrangean approach, solving the equation:

$$
X_{i}\left(x_{0}, y_{0}\right)^{n+1}=X_{i}\left(x_{0}, y_{0}\right)^{n}+\int_{t_{0}+n \Delta t}^{t_{0}+(n+1) \Delta t} U_{i}\left(x_{0}, y_{0}, t\right) d t
$$

at each time step. $X_{i}\left(x_{0}, y_{0}\right)^{n+1}$ is the position at the instant $n+1$ of the particle released at the point $X_{i}\left(x_{0}, y_{0}\right)^{0}$ (Dias, 2001; Dias et al., 2003). In this study the time integral was computed using a fourth-order Rung-Kutta scheme (Hofmann, Hedström, Moisan, Haidvogel \& Mackas, 1991; Dias, 2001; Dias et al., 2003):

The implementation of this model is straightforward, provided that a velocity field such as the one simulated by the two-dimensional hydrodynamic model is available. In reality, particles may move in response to additional processes such as diffusion, dissolution or aggregation and deposition, which are important in some areas of the lagoon. The implicit assumption made in this work was that the particle distribution was dictated primarily by passive advection within the 2-D flow field (Dias, 2001; Dias et al., 2003).

In this study, particle trajectories will be used to simulate the paths of microalgae in Ria de Aveiro. The microalgae are regarded as passive particles, i.e. the model assumes that they do not possess effective means of 
locomotion, their distribution being mainly due to the transport induced by tidal currents.

The time step and the grid used for the Lagrangean simulations were the same considered for the hydrodynamic model.

The accuracy of the particle-tracking model was tested by advecting a particle in a well-known velocity field. The particles were advected by a two-dimensional periodic velocity field, with a strong semidiurnal constituent and a weak diurnal one. The relations and values adopted are typical of Ria de Aveiro (Dias et al., 2001). The computed particle trajectory was compared with the trajectory determined by solving the analytical equations, and the results showed a good accuracy (Dias 2001; Dias et al., 2001).

\section{Results}

The model was used to simulate two different tidal cases (neap and spring tides) in September 2004. This period was chosen because during September toxic microalgae (namely Dinophysis acuta) are always observed in Ria de Aveiro (as shown in Figure 2). Simulations were performed with 3 particle emission points located at the lagoon mouth, during one tidal cycle, for extreme spring and neap tides (tidal ranges of 3.1 and $0.7 \mathrm{~m}$,

respectively). The highest and the lowest tidal prism in Ria de Aveiro (and therefore the maximum and minimum tidal currents) occur under extreme spring and neap tides, respectively. A tide prediction for September spring and neap tides was imposed at the ocean open boundary. Through this 
methodology the maximum and minimum trajectories performed by the microalgae in the lagoon were determined. The simultaneous trajectories obtained for all particles emitted were represented using animations (not shown). Assuming that microalgae behave in the same manner as particles, these animations revealed that their distribution in Ria de Aveiro lagoon is unquestionably determined by tidal currents. In the extreme spring tide case microalgae travel further into the lagoon than in the neap tide, affecting also a larger distribution area. Additionally, at the end of the ebb stage of the spring tide, some particles still remain inside the lagoon, near Triângulo das Correntes sampling station. For both tidal cases, microalgae transport occurs mainly into Espinheiro channel.

Other simulations were carried out for the same period, again during one tidal cycle during extreme spring and neap tides, with 15 emission points located along the lagoon mouth (particles released at the beginning of the local flood). The majority of the emitted particles did not return to the ocean after one tidal cycle, situation that did not allow the calculation of all the desired results. For that reason, further simulations, again with 15 emission points, were performed over a 4 day period starting at the same instants.

\subsection{Preferential channel}

Using the microalgae trajectories obtained for both simulations (tidal cycle period - $12.25 \mathrm{~h}$ and 4 day period $-96 \mathrm{~h}$ ), the channels into which microalgae were preferentially transported were determined (Figure 3).

The results reveal that microalgae transport occurred mainly into Espinheiro channel (45\% of the cases), followed by S. Jacinto channel (20\%), Mira 
channel (18\%) and finally to the Entrance channel (17\%). No microalgae transport to Ílhavo channel was recorded. These results were similar for neap and spring tides.

\subsection{Microalgal trajectories characterization}

Using the trajectories obtained for the 4 day period simulations in neap and spring tides, the distance attained by microalgae at each channel before returning back to the ocean (distance, $\mathrm{km}$ ) and the time needed to cover that distance (time, h), as well as the time that microalgae remained inside the lagoon before their exit (permanence time, h) were calculated. The residence

time for each channel was determined by subtracting the time microalgae needed to reach the far distance in that channel to the permanence time of microalgae in the lagoon. In this case the residence time should be interpreted as the time that particles emitted at the far distance in each channel take to leave the lagoon. The average results for the total number of simulations of each channel and for the simulations during spring and neap tides are summarized in Table 1.

The microalgae achieved greater distances within the lagoon in Espinheiro and S. Jacinto channels, $6.18 \mathrm{~km}$ and $5.21 \mathrm{~km}$, respectively. In Mira channel microalgae reached a $1.70 \mathrm{~km}$ distance during a $6.72 \mathrm{~h}$ period. Even though they achieve a shorter distance, the microalgae have a permanence time similar to that of Espinheiro channel. On average, the maximum distance travelled by microalgae before turning back to the ocean is shorter in the Entrance channel than in all others. In this case they always exit the lagoon in a time less than one complete tidal cycle $(8.66 \mathrm{~h})$. 
The S. Jacinto and Espinheiro channels present the higher permanence times and S. Jacinto channel also has the highest average residence time (39.26 h), corresponding to about 1 day $15 \mathrm{~h} 15 \mathrm{~min}$. The second highest average residence time occurs in Mira channel (12 h $15 \mathrm{~min}$ ), followed by Espinheiro channel (10 h $58 \mathrm{~min}$ ) and Entrance channel (1 h $31 \mathrm{~min})$.

To better understand how microalgal dispersal and distribution occurs in the different channels, due to their different hydrological characteristics, and the possible consequence in toxicity level found in bivalve shellfish, a more detailed characterization for each channel follows.

\section{ESPINHEIRO CHANNEL}

The microalgae trajectory maps obtained for this channel over a 4 day period simulation show that for both spring and neap tides, microalgae always reached the shellfish sampling stations located in this channel. Some times microalgae reached even more remote areas, being transported into the both branches that arise from Espinheiro channel (Figure 4).

The results obtained indicate that $60 \%$ of the microalgae leave the lagoon during the first tidal cycle. However, results (not shown) also indicate that on spring tides, microalgae can remain in the lagoon for a period of 22.74 to 36.28 h. On neap tides, this retention time can reach 49.62 h. This higher permanence time of microalgae inside the Espinheiro channel during neap tides is also demonstrated by the average results shown in Table 1 and by the trajectories presented in Figure 4(a) and (b), and is partially due to 
higher residence time (15 h 8 min) of microalgae in Ria de Aveiro during neap tides (Table1).

Even though the smaller time of microalgae permanence in Espinheiro channel during spring tides, when compared with the neap tide situation, the distance that they travel is higher (Table 1, Figure 4 (c)). These observations are in agreement with the average values of the calculated parameters shown in Table 1.

\section{S. JACINTO CHANNEL}

Microalgae trajectory maps obtained from the simulations over one single tidal cycle period showed that microalgae do not exit the lagoon in a period less than $12.25 \mathrm{~h}$, after their entrance in S. Jacinto channel.

The results obtained from a 4 day period simulation, during spring and neap tides, demonstrated that, most of the times, ebb currents were not strong enough to carry microalgae out of Ria de Aveiro during one tidal cycle being caught in the next flood current. In this situation they were transported back to S. Jacinto channel (Figure 5 (b)), where they reached areas far from the mouth, or were transported to the Espinheiro channel (Figure 5 (c)). In both cases the permanence time of microalgae inside the lagoon increases. An exception occurred in one simulation during spring tide when microalgae exit Ria de Aveiro in a period less than one tidal cycle (Figure 5 (a)).

Through the analysis of the other trajectories, it was observed that the permanence time of microalgae in the lagoon after their entrance in S. 
Jacinto channel, reached maximum values of $96.39 \mathrm{~h}$ (Figure 5 (b)) and of $49.04 \mathrm{~h}$ (Figure 5 (d)), for spring and neap tides, respectively. The maximum distance attained was $9.10 \mathrm{~km}$ (Figure 5 (b)) during spring tide and the minimum distance was $3.12 \mathrm{~km}$ during neap tide.

The analysis of Table 1 confirms the results discussed above. In addition to permanence time, average maximum distances attained by microalgae and time needed to cover those distances, were also higher for spring tide.

\section{Mira CHANNEL}

In the Mira channel microalgae dispersal presents a different pattern depending on the type of tide (spring or neap) that induces their transport. From the trajectories obtained with the 4 day simulations, it was found that during spring tides microalgae entry and departure from the Mira channel occurs on one tidal cycle (Figure 6 (a)). During neap tides, microalgae remain inside the lagoon for longer periods and are retained in the Triângulo das Correntes area. They can then be re-transported back into the lagoon, this time in the direction of Espinheiro channel (Figure 6 (b)).

The distance travelled by microalgae was approximately the same distance on spring and neap tides $(1.72 \mathrm{~km}$ and $1.69 \mathrm{~km}$, respectively), and the time needed for that transport is also much the same. The numerical results for microalgae permanence time and residence time (Table 4) agrees with the conclusions drawn from the analysis of the trajectory maps. 


\section{ENTRANCE CHANNEL}

In this channel, the average maximum distance travelled by microalgae is similar on spring and neap tides, as is the time needed to cover that distance (Table 5). Nevertheless, on neap tides a larger time for the microalgae to exit from the lagoon was found. This channel has an average residence time

of $1.53 \mathrm{~h}$ (Table 1), and maximums of this parameter are found during neap tides.

Both during spring and neap tides microalgae retention occurs close to the northern jetty of the inlet channel (Figure 7).

\section{Discussion}

The results obtained indicate that microalgae transport in Ria de Aveiro is greatly determined by the tidal currents. The longer distances travelled by microalgae, and larger distribution area, during spring tides are due to the stronger tidal currents induced by the higher tidal amplitude, characteristic of spring tides (The Open University, 1989), which transport microalgae further into the lagoon.

The microalgae retention near the area of Triangulo das Correntes at the end of the ebb stage of spring tides is probably a result of the higher distances that particles achieve in this type of tide. This result has considerable importance because it shows that a certain level of microalgal retention may exist at this area of Ria de Aveiro.

Both the simultaneous trajectories obtained for all particles at the same time and the simulations performed during the periods of $12.25 \mathrm{~h}$ and $96 \mathrm{~h}$ 
showed that microalgae transport occurs mainly into Espinheiro channel, followed by S. Jacinto channel. These results can be explained by the previous hydrological characterization of Ria de Aveiro performed by Dias (2001), that indicates a highest current flux in these two channels.

Since none of the simulations indicate transport of microalgae to Ílhavo channel, it is considered that it is not necessary to continue with the monthly common cockle sampling programme in this channel. The occurrence of significantly higher tidal currents that could induce microalgae transport to this channel is unlikely. In situations of flooding and increased river flow, besides the consequent decrease of the tidal currents in Ílhavo channel, the resulting higher influence of freshwater would be a strong restrictive condition for marine toxic microalgae and shellfish survival in this area. Even so, more simulations should be performed and collection of water and bivalve samples during periods of occurrence of toxic microalgae at the Ílhavo channel is advised, in order to confirm this hypothesis.

Microalgae achieved greater distances within the lagoon in Espinheiro and S. Jacinto channels probably due to the higher strength of the tidal currents that occur in these channels (Dias, 2001). In S. Jacinto channel, microalgae needed more time to travel a shorter distance and also to exit the lagoon than in the Espinheiro channel. Once more, the tidal currents pattern may explain this behaviour, since in S. Jacinto channel the tidal current intensity strongly reduces landward, while in Espinheiro channel it maintains its intensity. 
S. Jacinto channel possesses higher residence times due to the greater distances achieved by the microalgae. When microalgae start their path to exit the lagoon, carried by the ebb currents, they are caught by the next flood tide and consequently dispersed again into the channels. The residence time in Mira channel is not related to the distances that microalgae achieve, but with a certain level of retention that apparently occurs in the area of Triângulo das Correntes.

\section{ESPINHEIRO CHANNEL}

The higher distances travelled by microalgae during less time for the period of spring tides in Espinheiro channel are probably due to the stronger currents characteristic of spring tides, which transport microalgae to more remote areas of the channel more rapidly. During neap tides, lower current velocities reduce the microalgal transport into the channel and increase the time needed for that transport. Although the smaller distances travelled by microalgae during neap tides in this channel, the period that they remain inside the lagoon is higher than in spring tides. It is believed that this permanence time is increased by the time that microalgae take to exit the lagoon from the higher distance that they have attained (residence time).

The weaker currents of the ebb on neap tides can be responsible for this slower exit of microalgae from the lagoon in comparison with spring tide. On neap tides, particles that enter into Espinheiro channel do not exit the lagoon after one tidal cycle; they are transported back and forward inside the channel due to the influence of successive ebb and flood currents. 
These results show that the present bivalve shellfish sampling stations located at Espinheiro channel postulated by INIAP/IPIMAR may be considered adequate for monitoring purposes. Nevertheless, there are no records of microalgae concentrations that actually occur in this channel. Water samples collected at Marégrafo and Triângulo das Correntes sampling stations may provide information on the phytoplankton species that enter in Ria de Aveiro, including Espinheiro channel - since the main component of the tidal flow is directed to this channel - but do not provide the number of cells per litre of toxic microalgae that really occur at this channel. The knowledge of this concentration is important in studies of bivalve toxicity level and abundance of microalgae toxic species; the time that microalgae remain inside Espinheiro channel is considered enough for phytoplankton growth (Margalef, 1978), leading to high food availability to filter-feeding bivalve shellfish. If toxic microalgae are present in the set of phytoplankton species, time exposure of shellfish to those organisms will be higher and the level of toxicity found in their tissues will also increase. Therefore, the collection of water samples during an experimental period, at the same points and with the same periodicity of shellfish sampling is recommended. This procedure will show if there are significant differences between the phytoplankton species abundance in each location, and show whether the water sampling stations of Marégrafo and Triângulo das Correntes are enough to perform the HABs monitoring in Espinheiro channel. 


\section{S. JACINTO CHANNEL}

The results obtained for almost all trajectories for this channel indicate that microalgae remain inside the lagoon for periods longer than one complete tidal cycle. An exception was encountered, however, and it is believed that this different microalgal path was determined by the northward location of the particle emission point at the Ria de Aveiro mouth and its proximity with the land boundary. Microalgae proceeding from this point were subjected to a flood flux different from the main flux at the centre of the channel, which transports the microalgae to a small bay (S. Jacinto bay) near the entrance of S. Jacinto channel. This could have delayed the microalgae course and reduced the distance attained in the channel. This shorter distance $(5 \mathrm{~km})$ could be enough to lead the microalgae to exit the lagoon in a period of $11.18 \mathrm{~h}$, under the influence of the ebb current.

At this channel the higher values of the calculated parameters are found during spring tides. The stronger currents characteristic of this type of tide are believed to be the cause of the greater microalgae transport into $\mathrm{S}$. Jacinto channel. Due to the greater distances achieved, ebb currents were not strong enough to transport microalgae out of the lagoon. Instead, they were caught by the next flood current which carried microalgae to other areas of the lagoon, consequently increasing the period of retention. Considering the weaker tidal currents of neap tides it would be expected that microalgae permanence time would be enhanced, as happened in Espinheiro channel. However, it was found that this period was shorter than for spring tide. A probable explanation is the shorter distances that microalgae travel 
on neap tides. In fact, if microalgae are transported far from the mouth in S. Jacinto channel (as in spring tide), the local current intensity is strongly reduced (Dias et al., 2000) and they are trapped in the central area of the channel. In the Espinheiro channel the current intensity remains high even for large distances to the mouth, and therefore the microalgae are able to be transported back to the lagoon's mouth during the ebb.

The bivalve shellfish sampling stations are located in the central area of the channel, as well as in S. Jacinto bay and in Moacha. Therefore it is not considered relevant to add other sampling locations. Concerning water sampling, one monitoring station exists at Moacha, which is located close to the greatest distances attained by microalgae. The impact of the implementation of another water sampling point at the beginning of the channel could be evaluated; however, it is thought that no additional knowledge would be obtained, considering the good information on phytoplankton species composition and concentrations already obtained at Marégrafo and Triângulo das Correntes sampling stations. In conclusion, implementation of new sampling stations at S. Jacinto channel is not recommended. A weekly periodicity at Moacha water sampling station is considered necessary, since phytoplankton community composition can change in a week, due to the period that algae remain in this area (see Table 1 - average of $54.09 \mathrm{~h}$ and maximum of $96.39 \mathrm{~h}$ ).

\section{MiRA CHANNEL}

The permanence time of microalgae in the lagoon during neap tides is probably due to higher residence time, which is increased by the fact that 
microalgae are caught by the next flood current before they can exit the lagoon. Some are retained in the area of Triângulo das Correntes and then re-transported back into Ria de Aveiro, this time in the direction of Espinheiro channel (Figure 6 (b)).

The bivalve sampling stations in this channel are located close to the areas where microalgae are predicted to be by the simulations. As a result the location of these sampling sites is considered appropriate. The periodicity of bivalve collection is also considered sufficient, because microalgae are not preferentially transported into this branch. The water sampling is carried out in the same area as the bivalve shellfish collection, and for that reason it is also considered appropriated. However, since some species of microalgae are harmful even at low concentrations (Andersen \& Throndsen, 2003) it is recommended that more frequent water samples are collected, maybe twice a month.

\section{ENTRANCE CHANNEL}

The microalgae retention that occurs close to the northern jetty of the Entrance channel may be a result of the location of the microalgae emission point. Such emission was performed to the north of the lagoon mouth and, therefore, microalgae were possibly transported by a current with weaker velocity and different direction, due to the proximity of the land boundary, and thus different from the current of the central area of the channel. This situation is considered relevant for this particular study, because a dense common mussel bed exists at this jetty. If microalgae are retained at this location, the time exposure of bivalve shellfish to toxic microalgae is higher 
and this may increase the level of toxicity found in bivalve shellfish samples collected at this site (Triângulo das Correntes common mussel sampling station).

\section{Conclusions}

It has been demonstrated that numerical modelling provides a useful tool in the management and assessment of this coastal area, notably in the monitoring of toxic events related to the presence of marine toxic microalgae that enter in Ria de Aveiro. It has validated the location of water and shellfish sampling stations postulated by INIAP/IPIMAR, in the context of Plano Nacional de Salubridade de Bivalves for Ria de Aveiro. It has also provided additional knowledge about the horizontal distribution and dispersal of microalgae in this lagoon, showing that there are some areas where microalgae are retained, related to the pattern of currents in each channel. The reduced time and financial resources required to apply this methodology, compared to the costs implicated in conventional monitoring programmes should be emphasized.

The fact that the model does not take into account the vertical distribution patterns of microalgae, determined by light intensity, nutrients availability, water temperature and salinity (Valiela, 1995), constitutes a limitation that should be resolved by model enhancement, in agreement with Cembella et al. (2005). 
The microalgae horizontal distribution and dispersal in Ria de Aveiro are mainly due to tidal currents and the preferential channels to which microalgae are transported are Espinheiro and S. Jacinto channels.

The pre-existing shellfish sampling stations were considered adequate for the toxic microalgae monitoring program since they cover reasonably well the area of Ria de Aveiro most influenced by tidal currents and, consequently, the maximum area that microalgae can achieve in each channel in a few days.

The location of the water sampling stations and periodicity was considered adequate, but some refinements to the program are advised: (1) The collection of shellfish at Ílhavo channel was considered unnecessary but further studies are advisable to confirm this hypothesis; (2) The water sampling station Marégrafo should be maintained due to its ideal location at the entrance of the lagoon, which provides general phytoplankton species composition. The sampling periodicity at this site is also considered optimal (twice a week) bearing in mind the different times that microalgae remain in each channel; (3) The Triângulo das Correntes sampling station existence is debatable. On the one hand, it is important to maintain since it determines the abundance of toxic microalgae which affect the common mussel bed existing at the northern jetty of the inlet channel. On the other hand it is not fully established if it is enough to monitor Espinheiro channel since there is evidence of microalgae retention at Triângulo das Correntes area, which can lead to the overestimation of phytoplankton cells that enter both channels. Moreover, it is considered (confirmed by the experience of observation of 
phytoplankton samples of both stations) that the species composition found in Triângulo das Correntes is the same as found in Marégrafo. It is recommended to conduct a comparative study between the level of toxicity found in common mussel and toxic microalgae abundance encountered in water samples from Marégrafo and Triângulo das Correntes. The aim being to verify where the best correlation is established and to decide on the validity of the existing Triângulo das Correntes sampling station; (4) The water sampling station in Moacha (S. Jacinto channel) and the weekly periodicity of collection was considered enough; (5) Water sample collection in Mira channel should be increased to, at least, two times a month; (6) The implementation of a water sampling station close to the shellfish collection areas in Espinheiro channel is advisable.

\section{Acknowledgements}

Toxic microalgae abundance data and location of water and bivalve sampling stations were provided by INIAP/IPIMAR in the context of the project Plano Nacional de Salubridade de Bivalves.

\section{References}

Andersen P, Throndsen J (2003) Estimating cell numbers. In: Hallegraeff

GM, Anderson DM \& Cembella AD (eds) Manual on harmful marine microalgae (2nd ed). UNESCO Publishing, p 99-128.

Barrosa JO (1985) Breve caracterização da Ria de Aveiro. In: Jornadas da Ria de Aveiro, Vol. III - Recursos da Ria de Aveiro, Câmara Municipal de Aveiro, Portugal, p 9-14 
Cembella AD, Ibarra IA, Diogene J, Dahl E (2005) Harmful Algal Blooms and their assessment in fjords and coastal embayments. Oceanography 18 : $158-171$

Dias JM (2001) Contribution to the study of the Ria de Aveiro hydrodynamics. PhD dissertation, University of Aveiro, Aveiro, Portugal

Dias JM, Lopes JF (2006a) Calibration and validation of hydrodynamic, salt and heat transport models for Ria de Aveiro lagoon (Portugal). Journal of Coastal Research, SI 39 (in press)

Dias JM, Lopes JF (2006b) Implementation and assessment of hydrodynamic, salt and heat transport models: the case of Ria de Aveiro lagoon (Portugal). Environmental Modelling and Software 21: 1-15

Dias JM, Lopes JF, Dekeyser I (1999) Hydrological characterisation of Ria de Aveiro, Portugal, in early Summer. Oceanologica Acta 22: 473-485

Dias JM, Lopes JF, Dekeyser I (2000) Tidal Propagation in Ria de Aveiro Lagoon, Portugal. Phys Chem Earth (B) 25: 369-374

Dias JM, Lopes JF, Dekeyser I (2001) Lagrangian transport of particles in Ria de Aveiro lagoon, Portugal. Phys Chem Earth (B) 26: 721-727

Dias JM, Lopes JF, Dekeyser I (2003) A numerical system to study the transport properties in the Ria de Aveiro lagoon. Ocean Dynamics 53: 220231

Dronkers JJ (1964) Tidal Computations in Rivers and Coastal Waters. North-Holland Publishing Company, Amsterdam, The Netherlands 
FAO (2004) Marine Biotoxins, FAO Food and Nutrition Paper, 80. Food and Agriculture Organization of the United Nations, Rome. 278 pp.

Gesteira-Gomez M, Montero P, Prego R, Taboada JJ, Leitão P, RuizVillarreal M, Neves R, Perez-Villar V (1999) A two-dimensional particle tracking model for pollution dispersion in A Coruña and Vigo Rias (NW Spain). Oceanologica acta 22: 167-177

Hallegraeff GM (2003) Harmful algal blooms: a global overview. In: Hallegraeff GM, Anderson DM \& Cembella AD (eds) Manual on harmful marine microalgae (2nd edn). UNESCO Publishing, p 25-46.

Hallegraeff GM (1995) Harmful algal blooms: a global overview. In: Hallegraeff GM, Anderson DM \& Cembella AD (eds) Manual on Harmful Marine Microalgae (pp. 25-50). UNESCO Publishing.

Hofmann EE, Hedström KS, Moisan JR, Haidvogel DB, Mackas DL (1991) Use of simulated drifter tracks to investigate general transport patterns and residence times in the coastal transition zone. Journal of Geophysical Research 96 C8: 15041-15052

IOC (2005) The IOC harmful algal programme [on-line]. Intergovernmental Oceanographic Comission of UNESCO, Paris, France.[cited 26/09/2005] Available from:

<http://ioc.unesco.org/hab/intro.htm>

Inoue M, Wiseman Jr. WJ (2000) Transport, mixing and stirring processes in a Louisiana estuary: a model study. Estuarine, Coastal and Shelf Science 50: $449-466$ 
Jørgensen CB (1990) Bivalve filter feeding: hydrodynamics, bioenergetics, physiology and ecology. Olsen \& Olsen, Fredensborg, Denmark

Leendertse JJ (1987) Aspects of SIMSYS2D, a system for two-dimensional flow computation. Report R-3572-USGS. The Rand Corporation, New York, USA

Leendertse JJ, Gritton EC (1971) A water-quality simulation model for well-mixed estuaries and coastal seas: volume II, Computation Procedures. Memorandum R-708-NYC. The Rand Corporation, New York, USA

Margalef R (1978) Life-forms of phytoplankton as survival alternatives in an unstable environment. Oceanologica Acta 4: 493-508

Moita MT (1993) Development of toxic dinoflagellates in relation to upwelling patterns off Portugal. In: Smayda TJ \& Shimizu Y (Eds.) Toxic Phytoplankton Blooms in the Sea (299-304). Elsevier, Amsterdam, The Netherlands.

Moita MT, Silva AJ (2001) Dynamic of Dinophysis acuta, D. acuminata, D. tripos and Gymnodinium catenatum during an upwelling event of the Northwest coast of Portugal. In: Hallegraeff GM, Blackburn SI, Bolch CJ \& Lewis RJ (Eds.) Harmful Algal Blooms 2000, IOC of UNESCO

Moita MT, Palma AS, Vilarinho MG (2005) Blooms de fitoplâncton na costa Portuguesa. IPIMAR Divulgação n ${ }^{\circ}$ 31, Lisboa, Portugal

Palma AS, Vilarinho MG, Moita MT (1998) Interannual trends in the longshore variation of Dinophysis off Portuguese coast. In: Reguera B, Blanco J, Fernández ML \& Wyatt T (Eds.) Harmful Algae: 124-127 
Sampayo MAM, Alvito P, Franca S and Sousa I (1990) Dinophysis spp. toxicity and relation to accompanying species. In: Graneli E, Sundstrom B, Edler L \& Anderson DM (eds.) Toxic Marine Phytoplankton (215-220). Elsevier, New York

Santos MA, Costa JR (1985) Modelação matemática e gestão da qualidade da água em rios. Laboratório Nacional de Engenharia Civil, Lisboa, Portugal

Sobral MP, Vieira F, Sobral V (2000) Zonas de produção de moluscos bivalves da Ria de Aveiro. IPIMAR Divulgação nº 12, Lisboa, Portugal

Sournia A, Chretiennot-Dinet MJ, Ricard M (1991) Marine phytoplankton: how many species in the world?. Journal of Plankton Research 13: 10931099

Storer TI, Usinger RL, Stedbins RC, Nybakken JW (1991) Zoologia geral, 6th edn. Companhia Editora Nacional, São Paulo, Brasil

The Open University (1989) Waves, tides and shallow-water processes. Pergamon Press, Oxford, England, 186p

Vale P (2004) Biotoxinas marinhas. Revista Portuguesa de Ciências Veterinárias 99 (549): 03-18

Vale P, Cerejo M \& Vilarinho MG (2004). Toxin production by Dinophysis spp. at Ria de Aveiro, Portugal. In press in: Proceedings of 5th International Conference on Molluscan Shellfish Safety, Galway, Ireland, 14-18 June 2004 
Valiela I (1995) Marine ecological processes. Spinger-Verlag New York $544 p$

Vicente CM (1985) Caracterização hidráulica e aluvionar da Ria de Aveiro. Utilização de modelos hidráulicos no estudo de problemas da Ria. In: Jornadas da Ria de Aveiro, Vol III - Ordenamento da Ria de Aveiro. Câmara Municipal de Aveiro, Portugal 
TABLES

Table 1. Average distance attained by microalgae (distance), time needed to cover that distance (time), total time that microalgae remain inside the lagoon (permanence time) and residence time (here interpreted as the time microalgae take to exit the lagoon from the far distance they attained), for all simulations together (average) and for spring and neap tides separately, in the channels of Ria de Aveiro.

\begin{tabular}{|c|c|c|c|c|c|}
\hline Channel & Tide & $\begin{array}{c}\text { Distance } \\
(\mathbf{k m})\end{array}$ & $\begin{array}{c}\text { Time } \\
(\mathbf{h})\end{array}$ & $\begin{array}{c}\text { Permanence } \\
\text { time } \mathbf{( h )}\end{array}$ & $\begin{array}{c}\text { Resid. Time } \\
(\mathbf{h})\end{array}$ \\
\hline \multirow{3}{*}{ Espinheiro } & Average & 6.18 & 9.11 & 20.09 & 10.97 \\
\cline { 2 - 6 } & Spring & 6.69 & 8.12 & 15.54 & 7.41 \\
\cline { 2 - 6 } & Neap & 5.60 & 10.27 & 25.40 & 15.13 \\
\hline \multirow{3}{*}{ S. Jacinto } & Average & 5.21 & 14.82 & 54.09 & 39.26 \\
\cline { 2 - 6 } & Spring & 6.57 & 18.75 & 67.97 & 49.23 \\
\cline { 2 - 6 } & Neap & 3.85 & 10.90 & 40.20 & 29.30 \\
\hline \multirow{3}{*}{ Mira } & Average & 1.70 & 6.72 & 18.97 & 12.25 \\
\cline { 2 - 6 } & Spring & 1.72 & 7.00 & 11.13 & 4.13 \\
\cline { 2 - 6 } & Neap & 1.69 & 6.44 & 26.81 & 20.37 \\
\hline & Average & 1.52 & 7.13 & 8.66 & 1.53 \\
\cline { 2 - 6 } & Spring & 1.55 & 7.09 & 7.83 & 0.73 \\
\cline { 2 - 6 } & Neap & 1.50 & 7.16 & 9.22 & 2.06 \\
\hline
\end{tabular}




\section{FIGURE CAPTIONS}

Figure 1. Map of Ria de Aveiro lagoon and location in Portugal. Existing water and bivalve sampling stations.

Figure 2. Dinophysis acuminata and D. acuta abundance variation, from March 2004 to May 2005 in the sampling stations of Marégrafo (a), Triângulo das Correntes (b), Moacha (c) and Mira channel (d).

Figure 3. Preferential channel, in percentage, to which microalgae are transported.

Figure 4. Microalgae tracks in Espinheiro Channel for minimum permanence time in spring tide (a); maximum permanence time in neap tide (b); and maximum distance attained in spring tide (c).

Figure 5. Microalgae tracks in S. Jacinto Channel for minimum (a) and maximum (b) and permanence time (c) in spring tide and minimum permanence time (d) in neap tide.

Figure 6. Microalgae tracks in Mira channel for the minimum permanence time in spring tide (a) and the maximum permanence time in neap tide (b).

Figure 7. Microalgae tracks in Entrance channel for the minimum permanence time in spring tide (a) and the maximum permanence time in neap tide (b). 


\section{ACCEPTED MANUSCRIPT}

Fig 1:

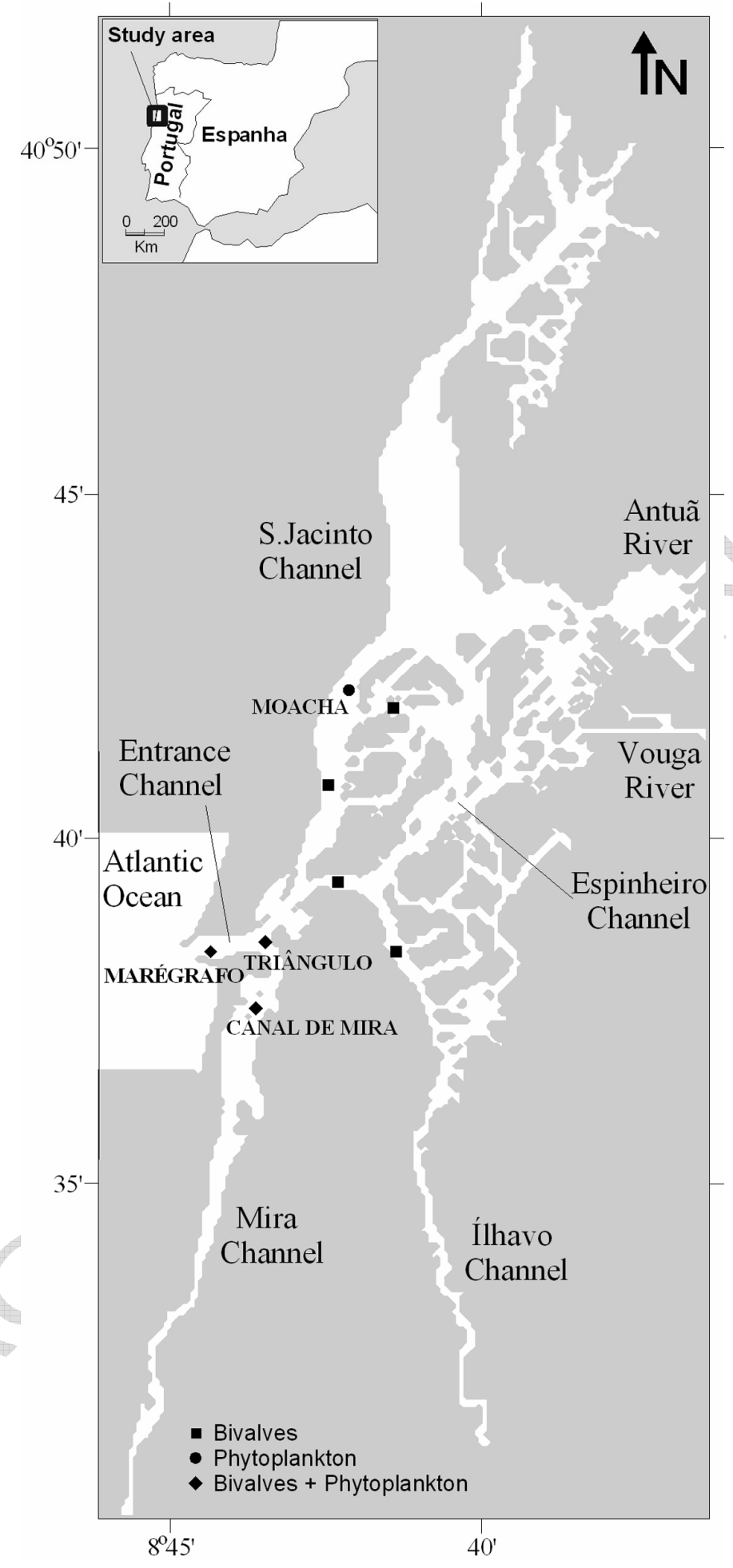


Fig 2a:

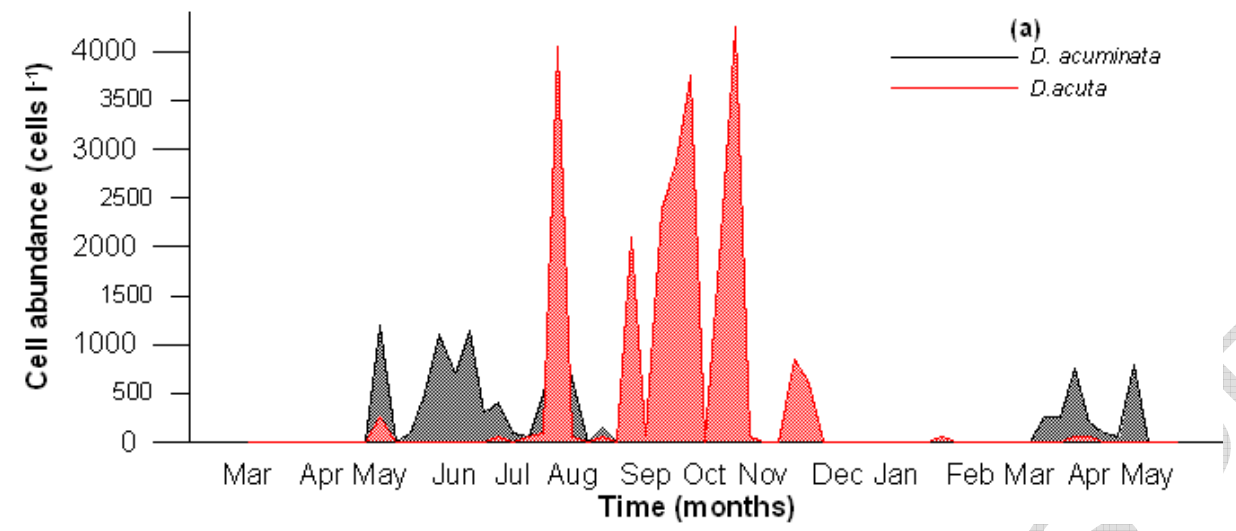

Fig 2b:

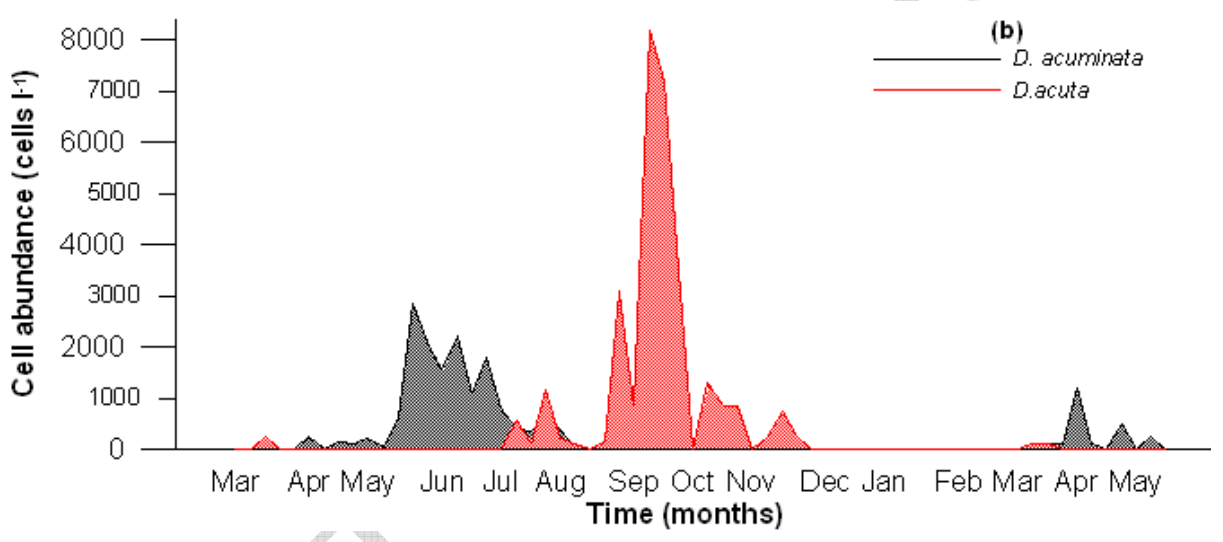


Fig 2c:

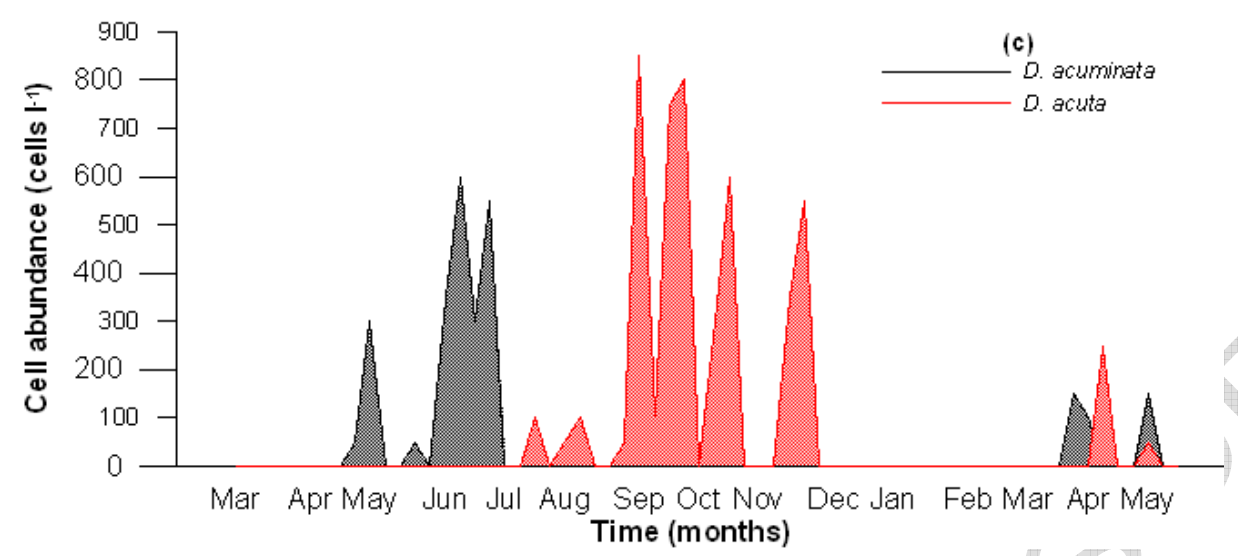

Fig 2d:

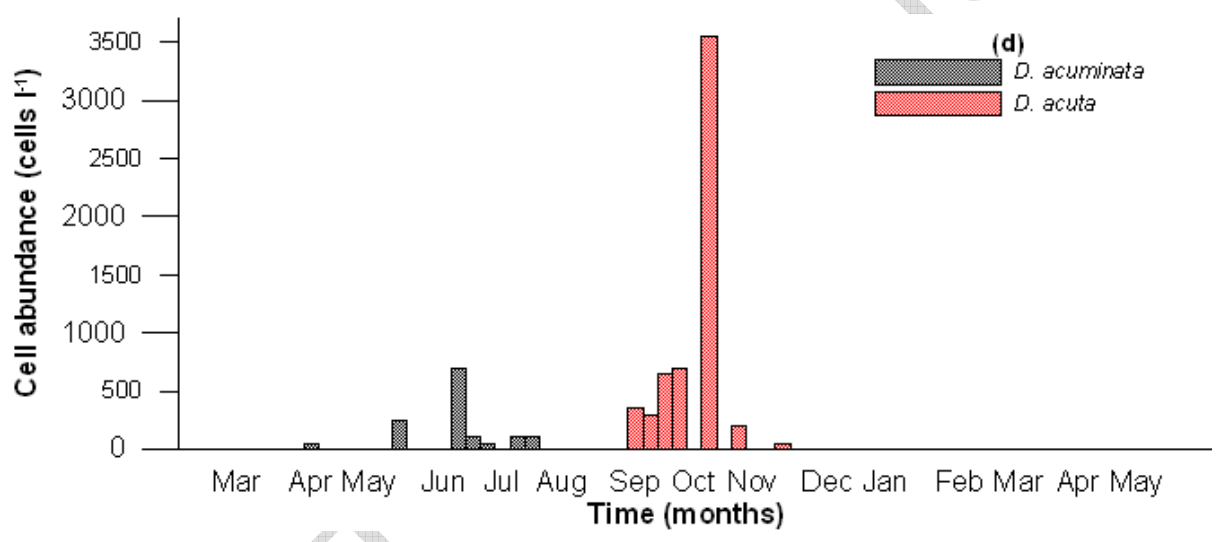


Fig 3:

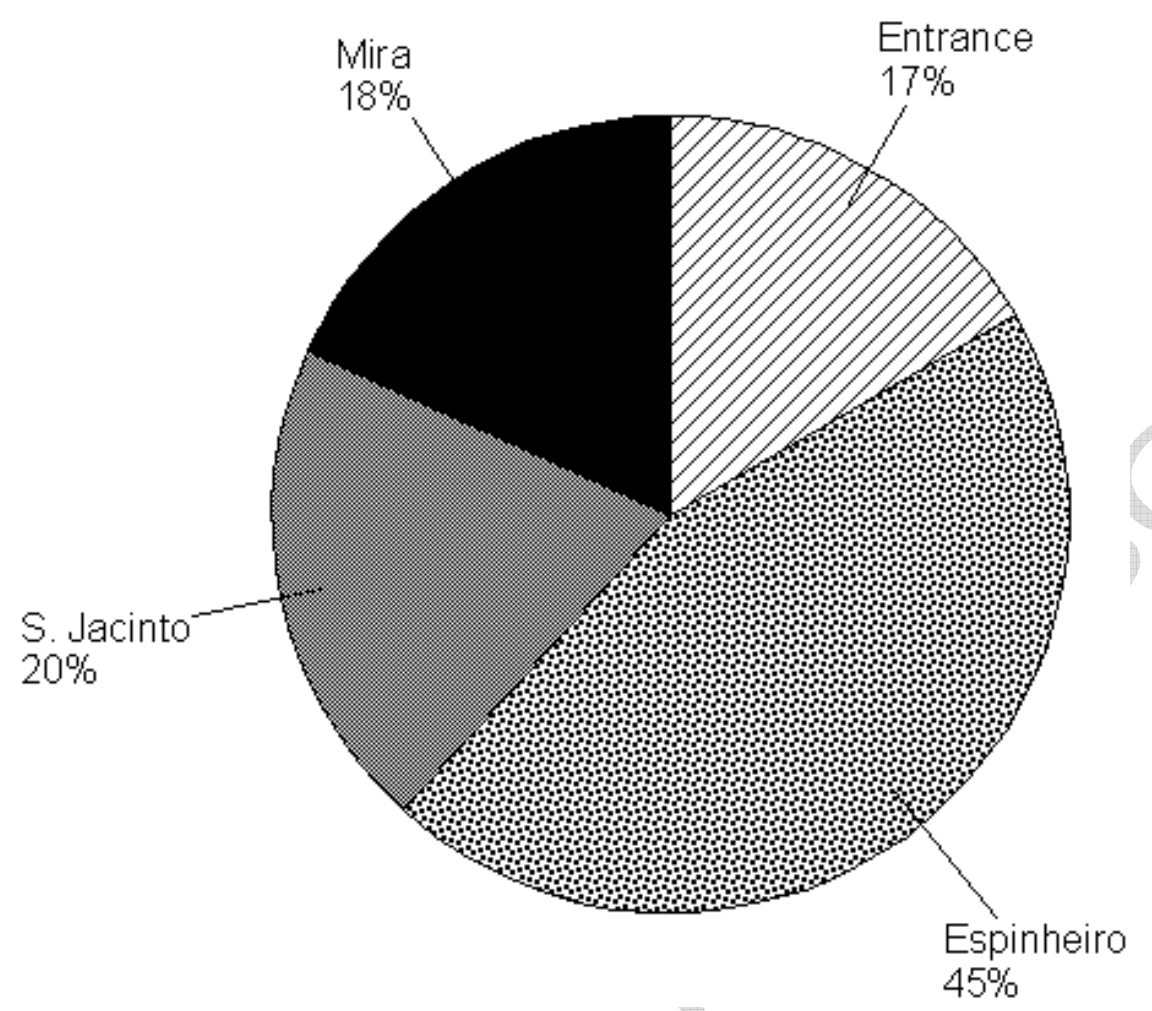




\section{ACCEPTED MANUSCRIPT}

Fig 4a

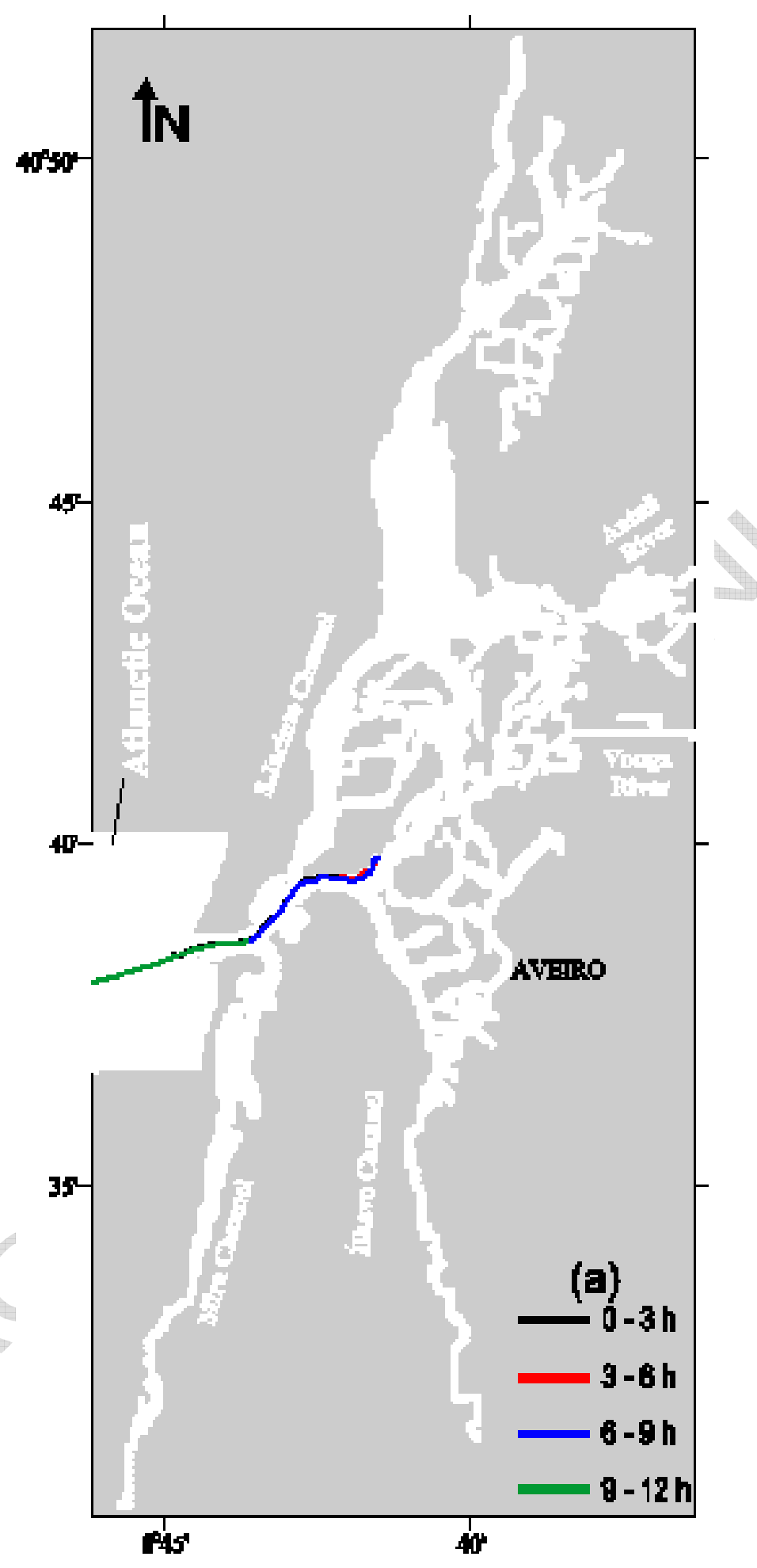




\section{ACCEPTED MANUSCRIPT}

Fig $4 b$

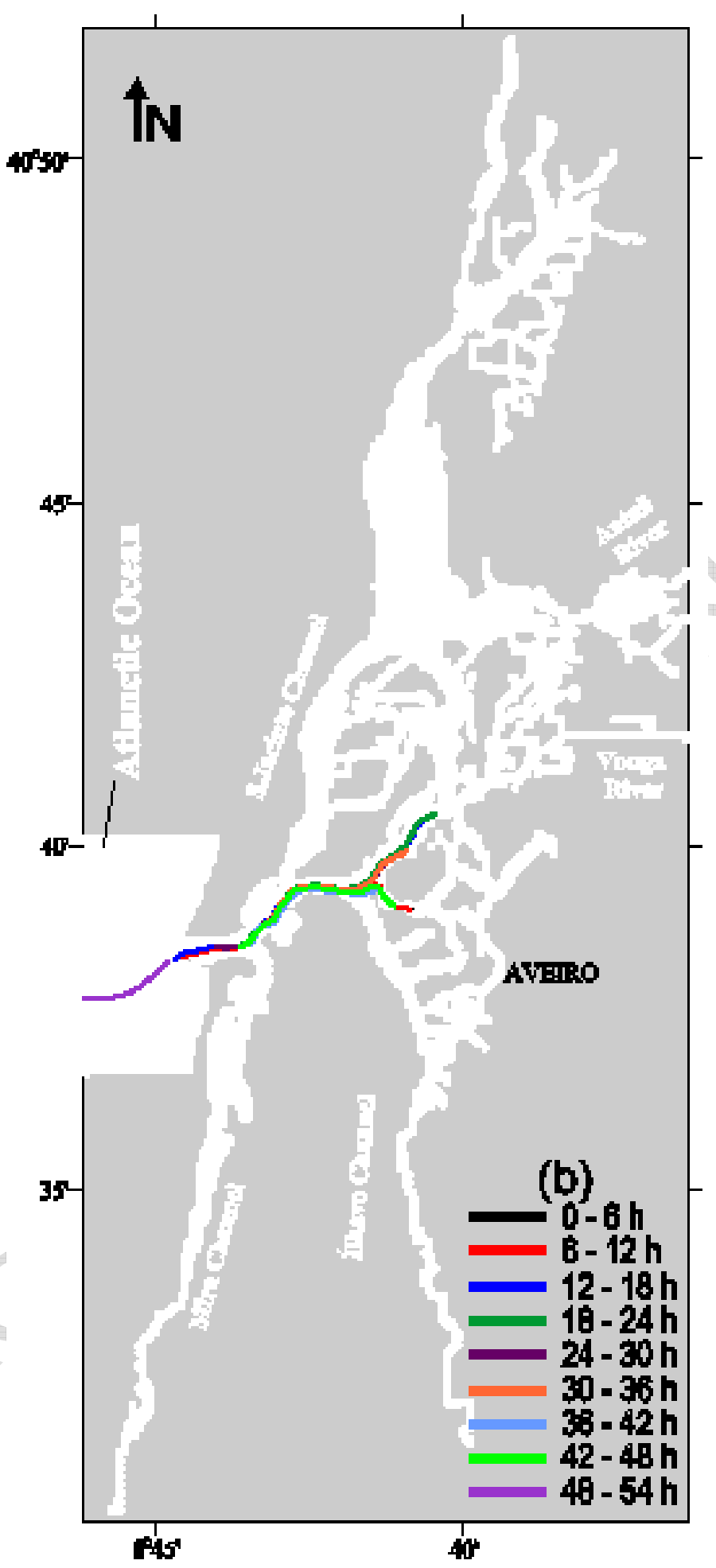




\section{ACCEPTED MANUSCRIPT}

Fig 4c

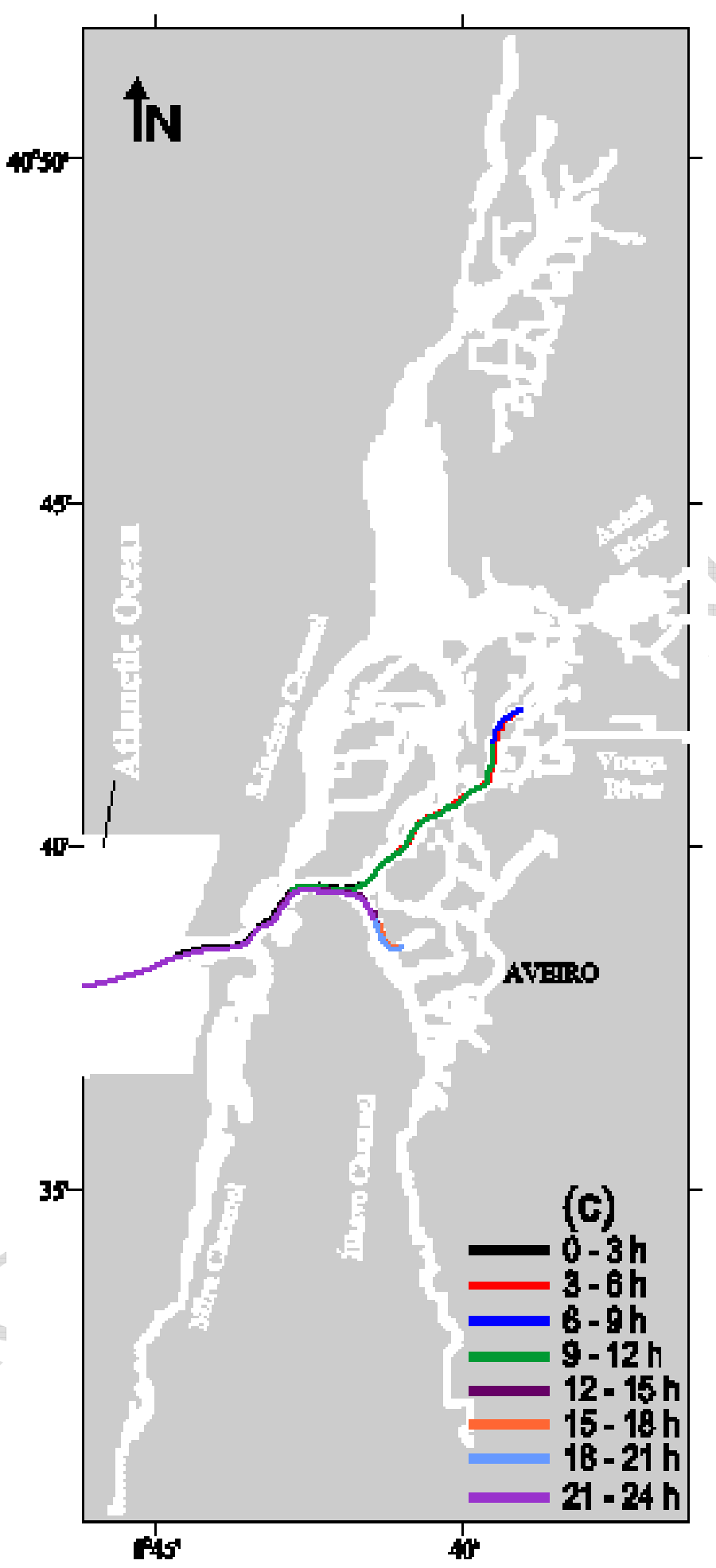




\section{ACCEPTED MANUSCRIPT}

Fig 5a

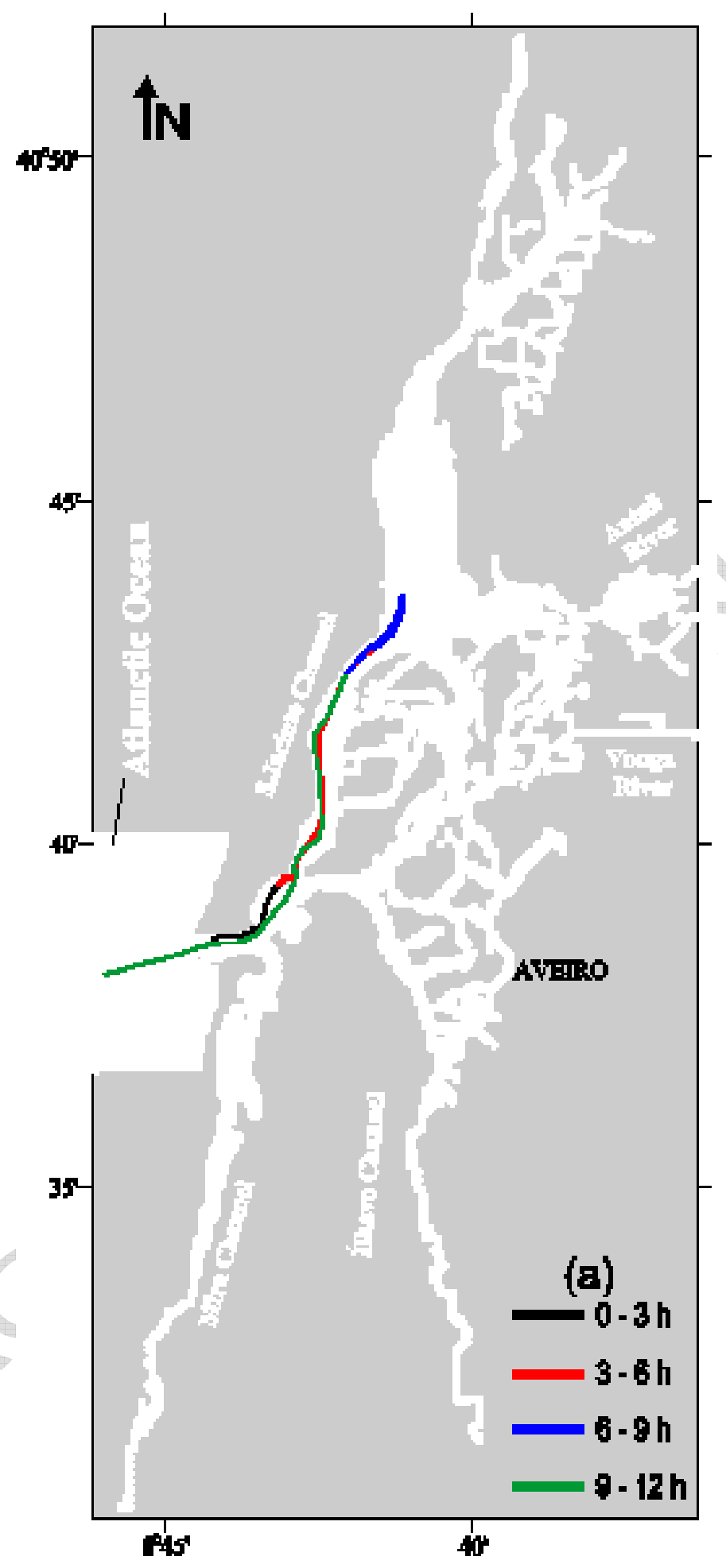




\section{ACCEPTED MANUSCRIPT}

Fig $5 b$

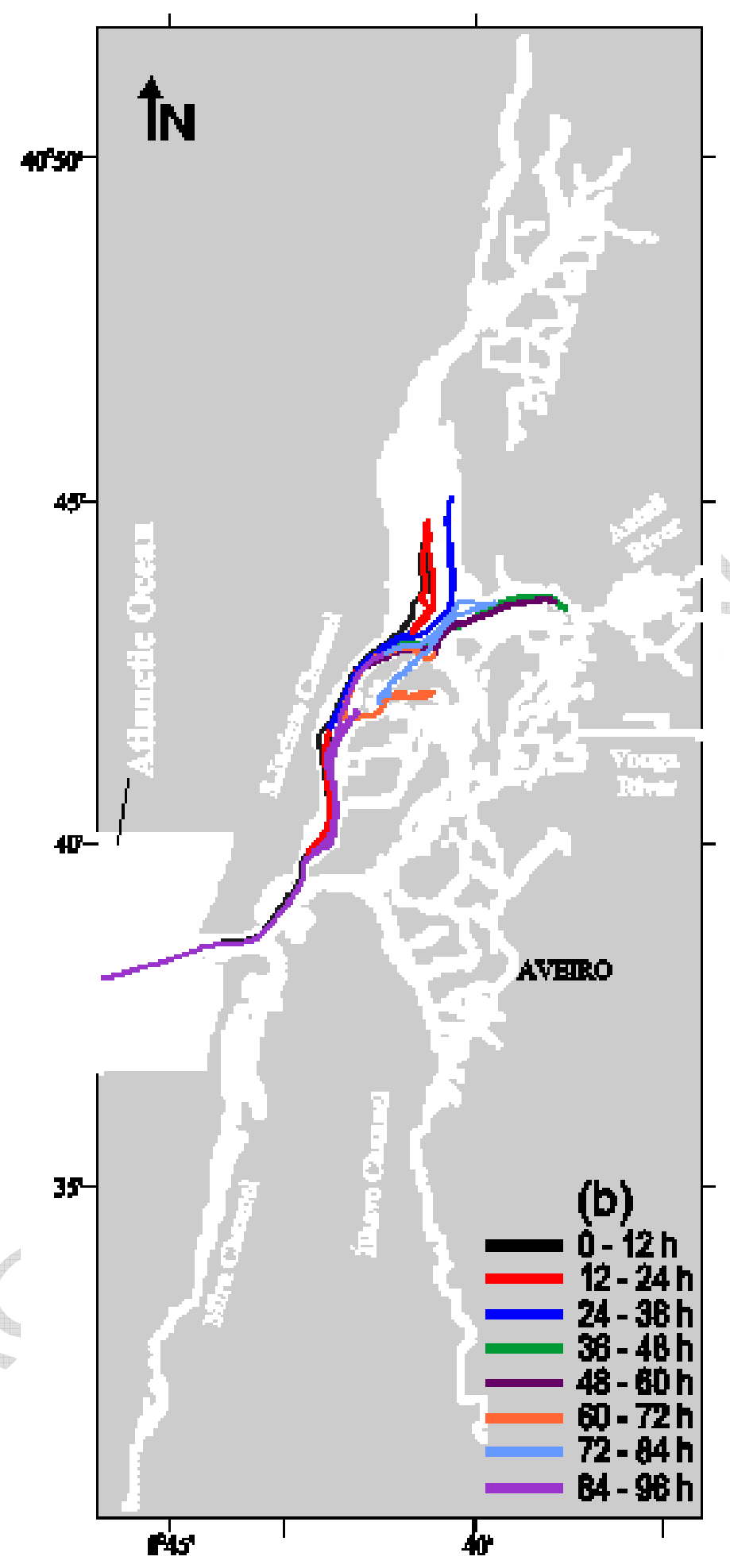




\section{ACCEPTED MANUSCRIPT}

Fig 5c

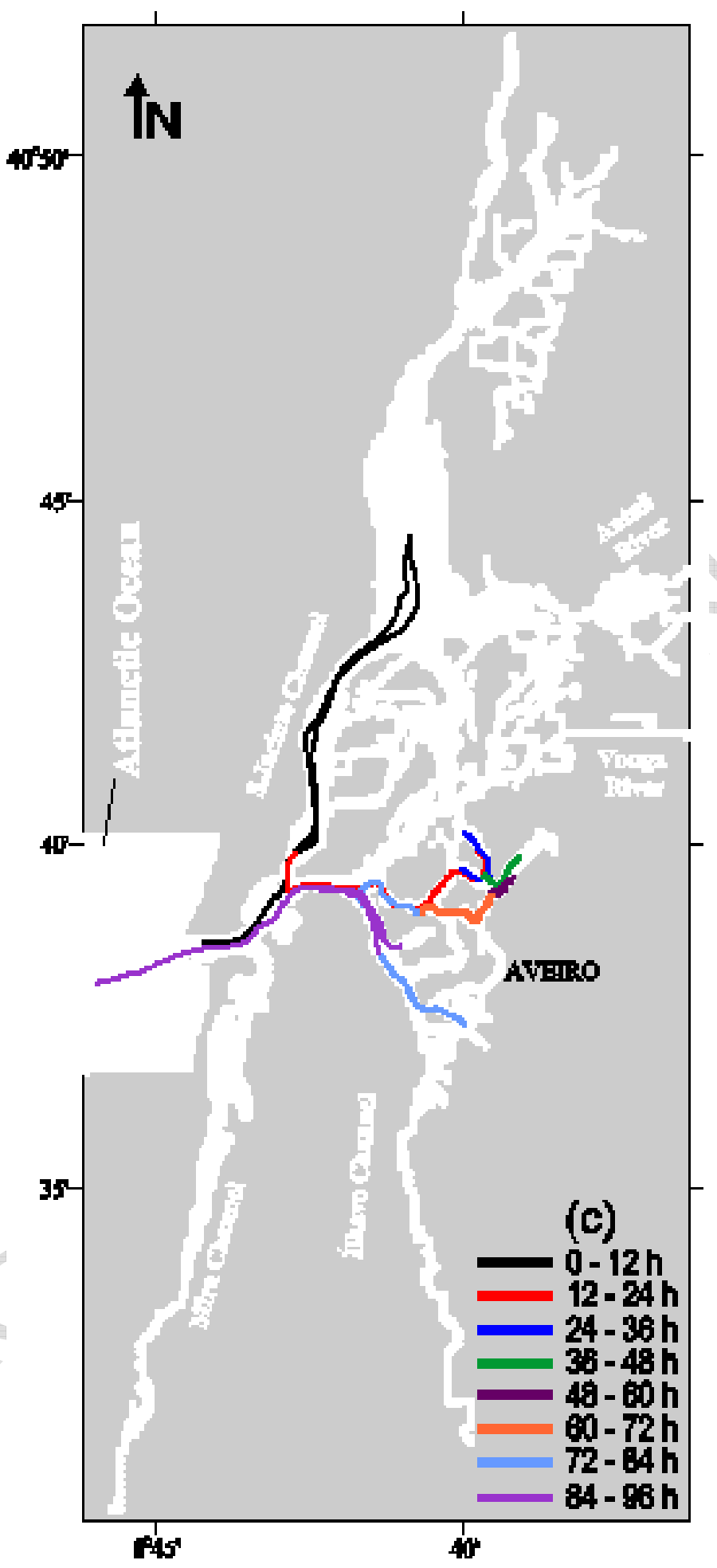




\section{ACCEPTED MANUSCRIPT}

Fig $5 d$

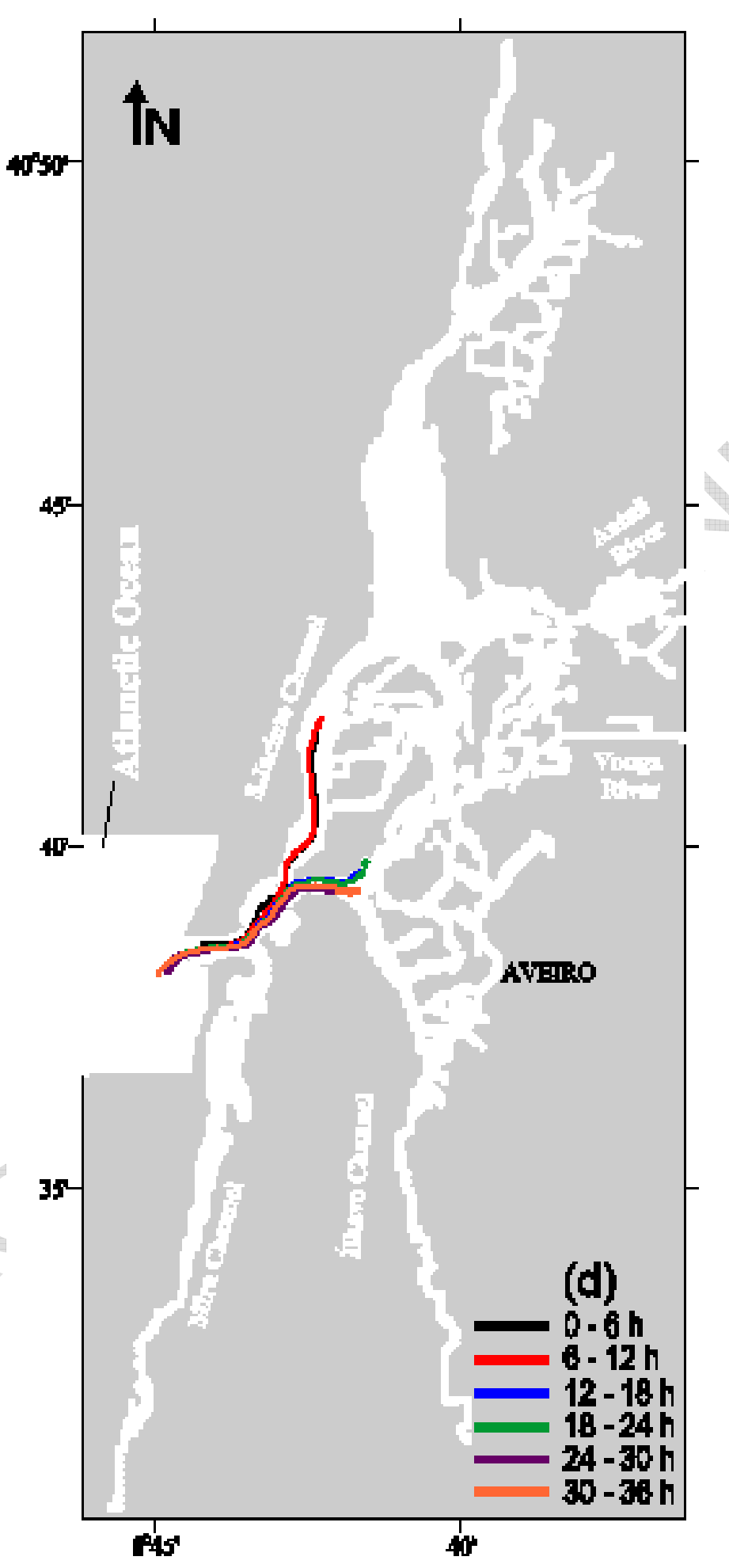




\section{ACCEPTED MANUSCRIPT}

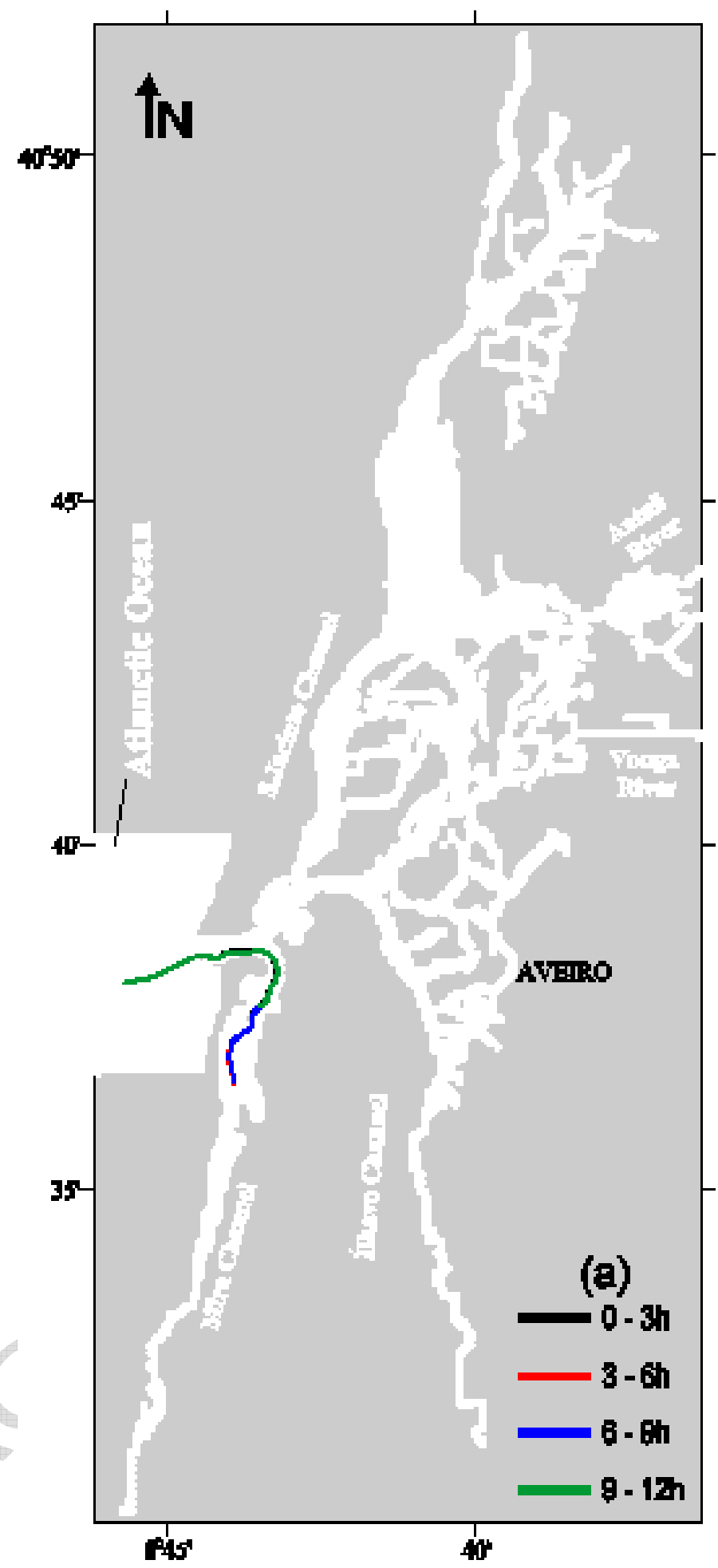

Fig 6a 


\section{ACCEPTED MANUSCRIPT}

Fig $6 b$

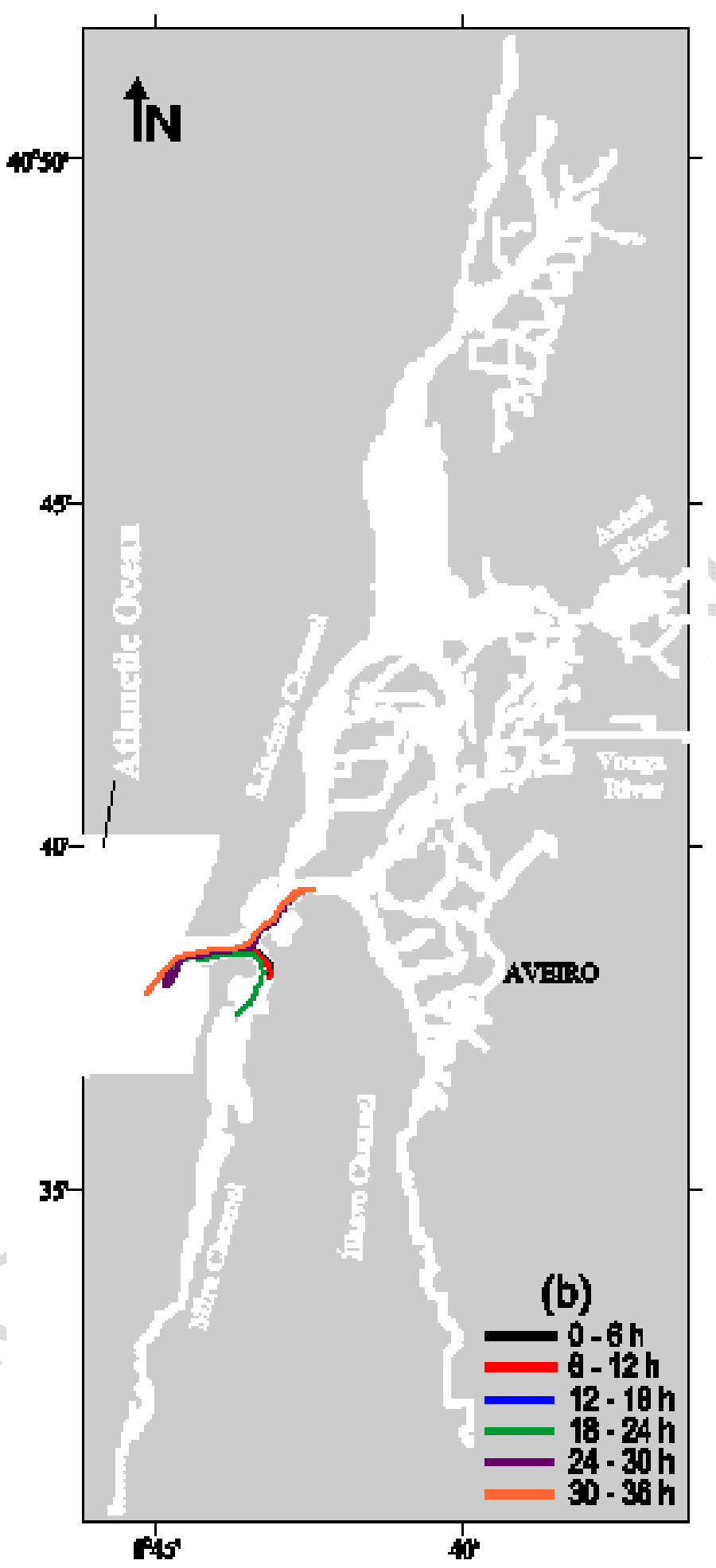




\section{ACCEPTED MANUSCRIPT}

Fig $7 \mathrm{a}$

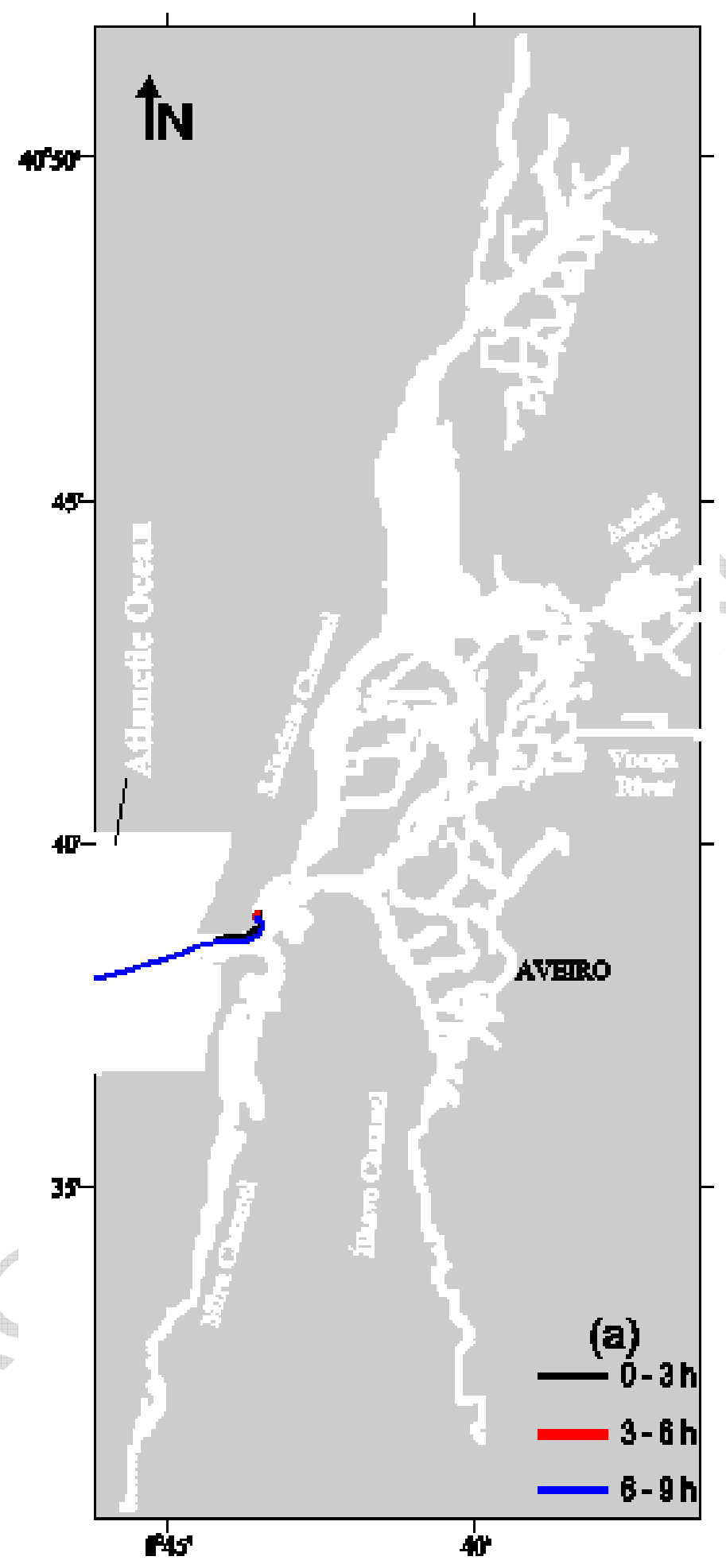




\section{ACCEPTED MANUSCRIPT}

Fig $7 b$

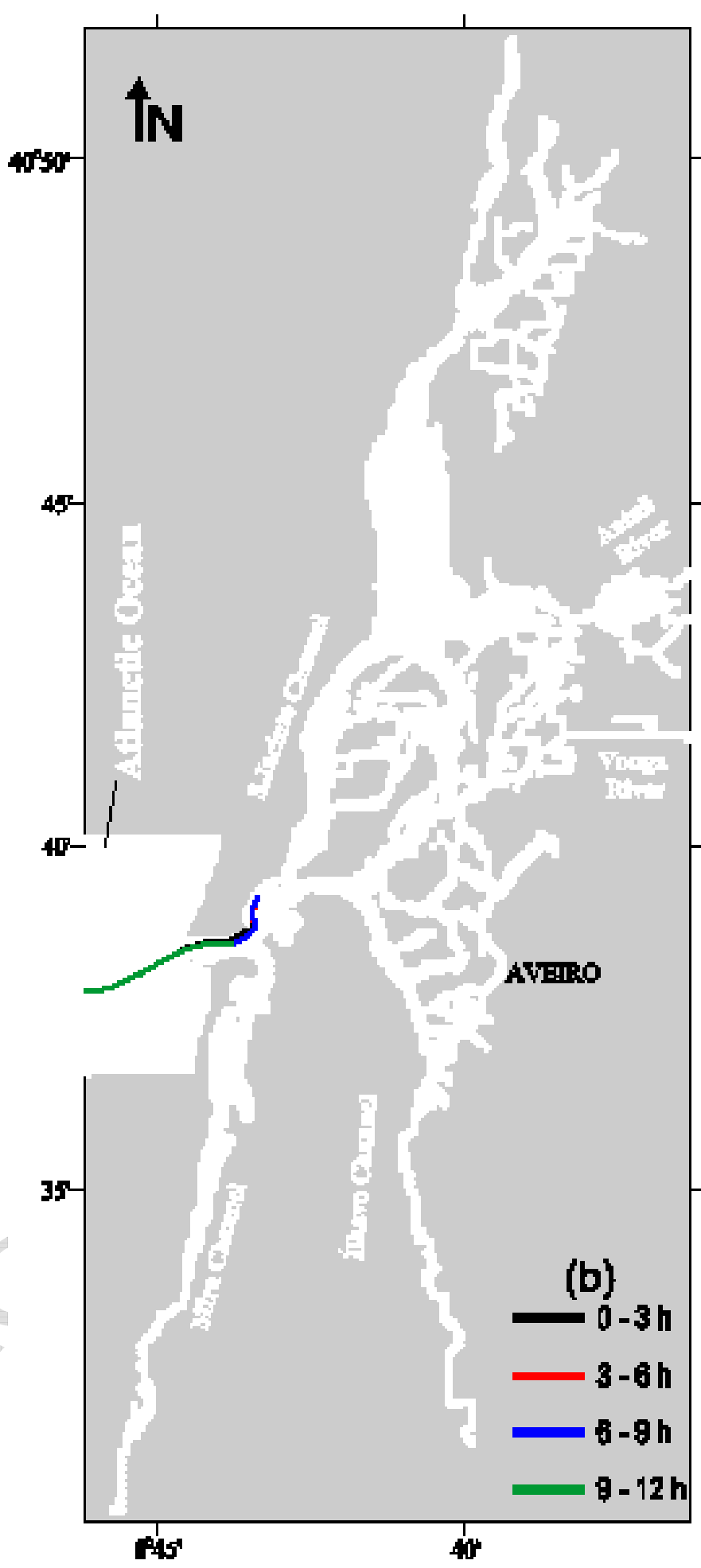

